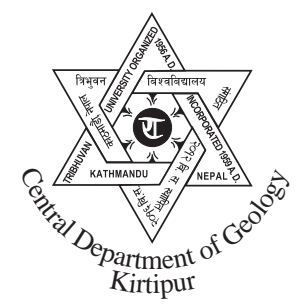

\title{
Evaluation of strength and durability of rocks from Malekhu-Thopal Khola area, Central Nepal Lesser Himalaya for construction aggregates
}

\author{
* Krishna Bista and Naresh Kazi Tamrakar \\ Central Department of Geology, Tribhuvan University, Kathmandu, Nepal
}

\begin{abstract}
Aggregate, the inert materials used in almost every field of modern development structures have great influence. Aggregates may look similar in appearance but they may carry different physical, mechanical and chemical properties and they may perform accordingly. End uses of aggregates are also determined by their performance. The Lesser Himalaya of the MalekhuThopal area comprises more than 14 formations having great potential of rock aggregates. The present study was carried out in order to reveal the toughness and soundness of each rock type of the Lesser Himalaya so that durability can be determined. Altogether 25 representative samples were tested to find porosity, specific gravity, dry density, uniaxial compressive strength (UCS), Los Angeles abrasion value (LAAV), aggregates impact value (AIV), sodium sulphate soundness Value (SSSV), ethylene glycol soaking value and water absorption value (WAV). Results were compared with standards of different specifications and recommended for wide range end uses.

Rock mass rating of each formation was carried out and the value ranges from 36 to 82 . Specific gravity ranges from 2.08 to 3.08 and the dry density ranges from 2.3 to $3.22 \mathrm{~g} / \mathrm{cm}^{3}$. All the samples have porosity less than $2 \%$ except the samples of the Benighat Slate. UCS value ranges from 5.9 to $301.9 \mathrm{MPa}$. The LAAV of the sample lies between $19.6 \%$ and $47.5 \%$. AIV is between $8.54 \%$ and $34.28 \%$. The SSSV ranges from 2.35 to $26.06 \%$. Ethylene glycol soak index is 2 of all samples signifying that proportion of swelling clays or low accessibility of ethylene glycol through the samples due to low porosity. WAV of all the samples is below $2 \%$ except the Benighat Slates which indicates that the aggregates have low effective porosity. The entire test shows that most of the sample meets different national and international standards and can be recommended for wide range of end uses.
\end{abstract}

Key words: Aggregates, durability, index properties, strength, Los Angeles abrasion, rock mass rating

Received: 10 March, 2015

Accepted: 15 June, 2015

\section{INTRODUCTION}

Development structures are the infrastructures of the nation. The infrastructures of the development should be strong enough to resist the load, and durable enough to run for several decades. More than $90 \%$ of asphalt pavement and $80 \%$ of concrete consist of construction aggregate. Crushed stones and sand and gravel share subequal proportion to the construction aggregate source. A typical pavement layer requires about 2000

\footnotetext{
*Corresponding author:

E-mail address: amateurbista05@yahoo.com
}

cubic meter of selected material per kilometer (PaigeGreen, 2004). The key properties of aggregate such as petrographical and physical properties have a bearing effect on engineering application (Přrikryl, 2001; Akesson et al., 2001; Al-Harthi, 2001; Azimah and Colin, 2010). Poor aggregates in terms of durability may have disastrous consequences. Therefore, its quality is of significant importance. The MalekhuThopal Khola area possesses more than fifteen geological formations and has got great potential of rock aggregates. Several quarry sites are running on the banks of these rivers. Therefore, the durability of rock 
aggregates of each formation is important to be studied well before using them in various development structures but not any kind of such studies has been done yet.

Smith and Collis (1993) identified main factors influencing aggregate behavior in various operational and environmental conditions, and relevant standards and other specifications and code of practice. They concluded that the performance of aggregates depends upon their intrinsic properties. Physical and mechanical properties of the Lesser Himalayan rocks and the SubHimalayan rocks were studied by several workers (Tamrakar et al., 2002; Maharjan and Tamrakar, 2003; Dhakal et al., 2006; Khanal and Tamrakar, 2009; Paudel, 2012). Tamrakar et al. (2002) determined dry density and porosity of Siwalik sandstones from the Central Nepal and concluded that these properties were related well with uniaxial compressive strength, point load index and modulus ratio. Dhakal et al. (2006) studied freeze-thaw experiments on the limestones and sandstones from Japan, and dolomite and schist from Nepal and concluded that initiation and extension of cracks and subsequent wearing and deterioration occurred relatively faster in the rock having a high porosity. The durability of freeze-thaw was also greatly influence by mineralogy.

Maharjan and Tamrakar (2007) determined dry density of samples from the Rapti Rivers between 2460 and $2680 \mathrm{~kg} / \mathrm{m}^{3}$, aggregate impact values between $14.2 \%$ and $16.1 \%$, and magnesium sulphate soundness values between $4.46 \%$ and $7.29 \%$ suggesting good resistance against chemical weathering and frosting, good soundness, durability and workability of those gravels for road and concrete aggregates.

Analysis of physical, mechanical and petrographical properties of sandstones from the Siwalik Group was made by Tamrakar et al. (2007) and concluded that the strength of the sandstone depends upon the \% void, strong over weak contacts, strong cement over total cement, packing density and concavo-convex contacts among grains. Quality of crushed limestone and siltstone for road aggregates from Adeshwar area Sitapaila, Kathmandu was studied by Khanal and Tamrakar (2009). They analysed rock mass condition of the outcrop and physical, mechanical, chemical and petrographical properties of three distinct varieties of rocks as crystalline limestone, siliceous limestone and calcareous siltstone. They concluded that the aggregates performed better for unbound pavement in roads. Maharjan and Tamrakar (2003) studied and concluded that the metasiltstones from the Tistung Formation, Nallu Khola, Tikabhairav area, Kathmandu Valley, were physically, mechanically and chemically sound and are appropriate for concrete aggregates.

Raghubansi and Tamrakar (2011) studied physical, mechanical and petrographical properties of the Higher Himalayan rocks from the Chaktan Ghasa-Kaligandaki River. They compared the Los Angeles abrasion value of schistose marble with those of augen gneiss and banded gneiss, and concluded that the carbonate minerals could have bonded strongly the other mineral constituents and yielding low Los Angeles abrasion value. They also analysed point load value and concluded that the weak bonding of mineral grains existed perpendicular to foliation plane.

The quality of the aggregates is driven by toughness and soundness which are studied by carrying out physical, mechanical and chemical tests. Durability is the ability of the materials to withstand the effects of environmental conditions, such as water, ageing and temperature variations without any significant deterioration for an extended period (Scholtz and Brown, 1996; Suparma, 2001). Durability i.e. toughness and soundness can be studied by collecting required information along with adequate sample tests. Samples that perform well in all tests are considered as the quality rock aggregates and can be used for several construction purposes. Thus, the main objectives of this study are to determine durability of crushed rock aggregates and evaluate suitability for end-use of these aggregates.

\section{GEOLOCAL SETTING}

The Malekhu-Thopal Khola area is located at about $70 \mathrm{~km}$ west of the Kathmandu Valley (Fig. 1) and falls within the Dhading District of the Bagmati Zone. The area is linked with the Prithvi Highway, which is considered as a channel linking Kathmandu with Pokhara and other major cities of the country. In this area there are mainly two big rivers: Trishuli Ganga in the east and Buri-Gandaki in the west. The Malekhu, 
Thopal, Galdu, Charongli and the Tuni Kholas are the major river system of medium sized. The Malekhu Khola flows from SE to NW and the Thopal Khola from NW to SE. Both kholas meet the Trisuli Ganga River.

The study area extends from the Kuncha Formation of the Lower Nawakot Group to the Tistung Formation of the Phulchauki Group of the Kathmandu Complex (Fig. 2). The study comprises 15 formations of the Lesser Himalaya except the Markhu Formation. The Markhu

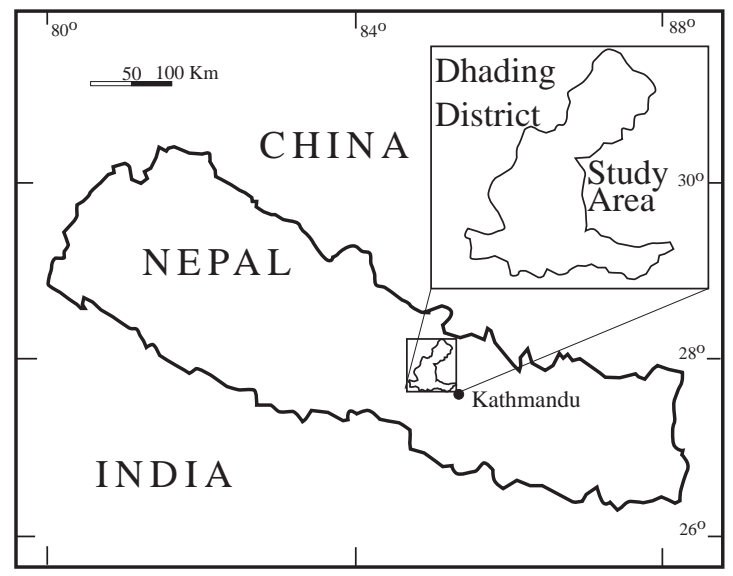

Fig. 1 Location map of the study area

Formation was not well exposed along the Malekhu Khola. The Kathmandu complex is further divided into two groups, viz. the Precambrian Bhimphedi Group consisting of relatively high-grade metamorphic rocks, and the Phulchauki Group of metasedimentary rocks and sedimentary rocks containing fossils of lower-middle Paleozoic age (Stöcklin and Bhattarai, 1977; Stöcklin, 1980). The Phuchauki Group is further subdivided into the Tistung Formation, the Sopyang Formation, the Chandragiri Limestone, the Chitlang Formation, and the Godavari Limestone from the older to the younger sequence. The Bhimphedi Group is also divided into the Raduwa Formation, the Bhaisedobhan Marble, the Kalitar Formation, the Chisapani Quartzite,

Fig. 2 Geological map of the study area

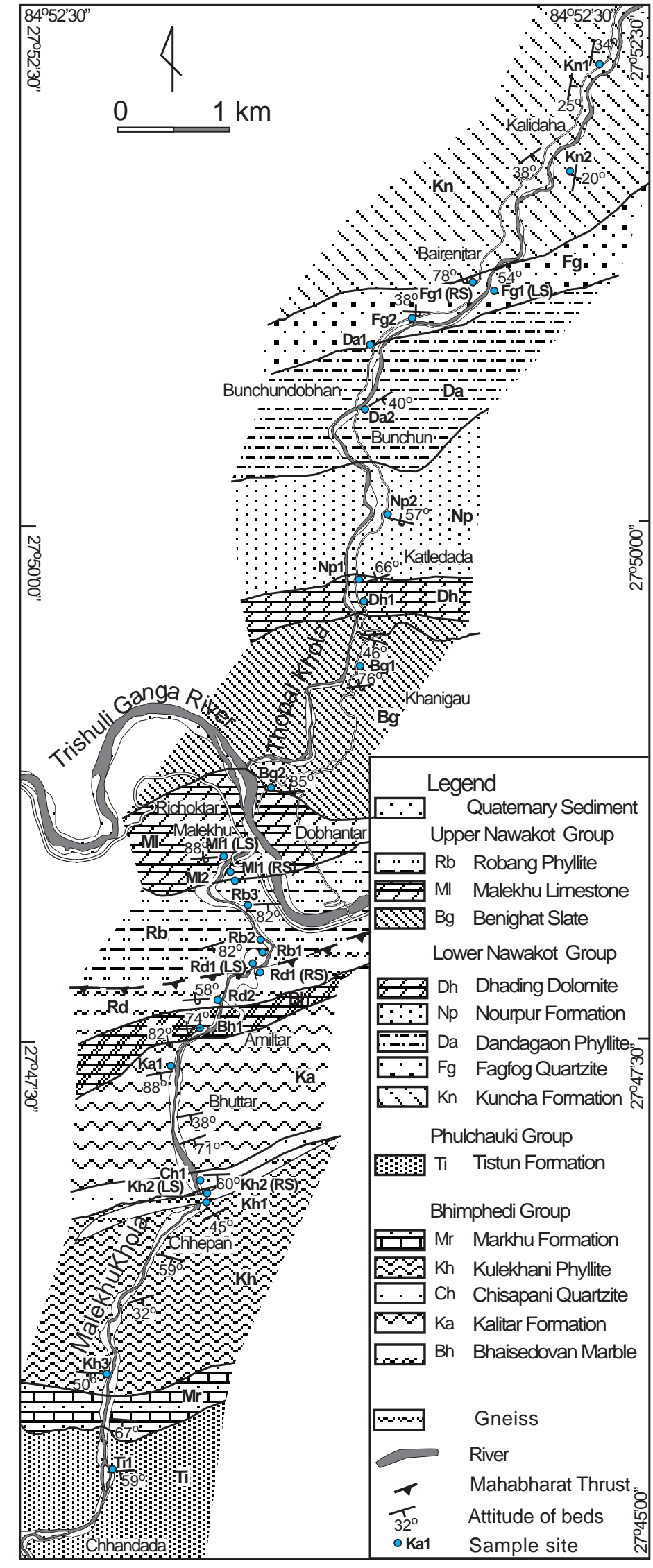


the Kulekhani Formation, and the Markhu Formation. The low-grade metasedimentary rocks of the Nawakot Complex have been subdivided into the Lower and the Upper Nawakot Groups. Stöcklin and Bhattarai (1977) and Stöcklin (1980) have worked out a detailed stratigraphy of the Nawakot Complex in the surrounding of the Kathmandu Nappe. The Lower Nawakot is further divided into the Kuncha Formation, the Fagfog Quartzite, the Dandagaon Phyllite, the Nourpul Formation, and the Dhading Dolomite from the lower to the upper sequence. The Upper Nawakot Group, comprising of the Benighat Slate, the Malekhu Limestone and the Robang Formation, unconformably overlies the Upper Nawakot. The proposed study area comprises the geological formations of the Lower Nawakot Group and the Benighat Slates of the Upper Nawakot Group across the Thopal River, while the Malekhu Limestone and the Robang Formation of the Upper Nawakot Group, the units of the Bhimphedi Group, and the Tistung Formation of the Phulchauki Group of the Kathmandu Complex across the Malekhu River. The Mahabharat Thrust (MT) separates the Nawakot complex from the Kathmandu Complex (Table 2.1; Fig. 2)

\section{METHODOLOGY}

The study was categorized into four: desk study, field study, laboratory works, data processing and interpretation. The desk work consisted of preparatory works. The field work was carried out for geological traverse along Malekhu Khola, Thopal Khola and the Malekhu-Dhading Road section. The Rock Mass Rating was made after Bieniawski (1989). Fresh samples about 4 to $7 \mathrm{~kg}$ were collected from each location for the laboratory study and the locations were marked in the topo-sheet.

Several tests were carried out in the different labs according to the availability of the resources. Thin section preparation, petrographic study, water absorption test, dry density test and chemical tests were done in the Central Department of Geology, TU Kirtipur. Aggregate impact test and point load test were conducted in the NEA lab, Swayambu, Kathmandu. Similarly, Los Angeles abrasion test was done in the Rock, Soil and Construction materials testing laboratory of Pulchowk Engineering Campus, Pulchowk Lalitpur.

Table 2.1: Stratigraphic sub-division of Central Nepal Lesser Himalaya (After Stöcklin and Bhattarai, 1977 and Stöcklin, 1980)

\begin{tabular}{|c|c|c|c|c|c|}
\hline Complex & Group & Formation & Main lithology & $\begin{array}{l}\text { Thickness } \\
\text { (m) }\end{array}$ & Age \\
\hline \multirow{11}{*}{ 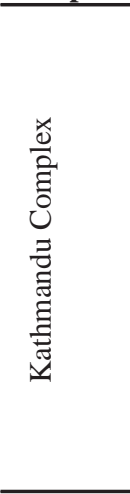 } & \multirow[t]{5}{*}{ Phulchauki } & Godawari Limestone & Limestone & $300-400$ & Devonian \\
\hline & & Chitlang Formation & Slate, Quartzite & 1000 & Silurian \\
\hline & & Chandragiri Limestone & Limestone & 2000 & Cambrian \\
\hline & & Sopyang Formation & Slate, calc. Phyllite & 200 & Cambrian (?) \\
\hline & & Tistung Formation & Metasandstone, Phyllite & 300 & $\begin{array}{l}\text { Early Cambrian or } \\
\text { Late Precambrian }\end{array}$ \\
\hline & \multirow[t]{6}{*}{ Bhimphe } & Markhu Formation & Marble, schist & 1000 & Late Precambrian \\
\hline & & Kulekhani Formation & Quartzite, schist & 2000 & Precambrian \\
\hline & & Chisapani Quartzite & White quartzite & 400 & Precambrian \\
\hline & & Katitar Formation & Quartzite, schist & 2000 & Precambrian \\
\hline & & Bhainsedobhan Marble & Marble & 800 & Precambrian \\
\hline & & Raduwa Formation & Garnetiferous schist & 1000 & Precambrian \\
\hline & & .........Mahabharat Thr & 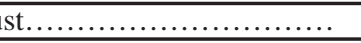 & & \\
\hline \multirow{9}{*}{ 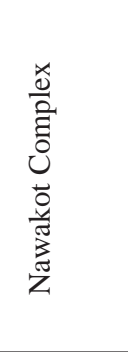 } & Upper & Robang Formation & Phyllite, Quartzite & $200-1000$ & Early Paleozoic \\
\hline & Nawakot & Malekhu Limestone & Limestone, Dolomite & 800 & Early Paleozoic \\
\hline & Group & Benighat slate & Slate, argillaceous dolomite & $500-3000$ & Early Paleozoic \\
\hline & \multicolumn{5}{|c|}{ Unconformity } \\
\hline & Lower & Dhading Dolomite & Stromatolitic dolomite & $500-1000$ & Precambrian \\
\hline & Nawakot & Nourpul Formation & Phyllite, Metasandstone & 800 & Precambrian \\
\hline & Group & DandagaunPhyllite & Phyllite & 1000 & Precambrian \\
\hline & & Fagfog Quartzite & White Quartzite & 400 & Precambrian \\
\hline & & Kuncha Formation & Phyllite, Quartzite & 3000 & Precambrian \\
\hline
\end{tabular}




\section{Durability of aggregates}

Aggregate is commonly considered inert filler, which accounts for 60 to 80 percent of the volume and 70 to 85 percent of the weight of concrete. Although aggregate is considered inert filler, it is a necessary component that defines the concrete's thermal and elastic properties and dimensional stability (Mehta and Monterio, 1993). Durability of the rock aggregates, which is contributed by toughness and soundness, was accessed via physical, mechanical and chemical tests.

\section{Toughness}

Toughness describes how much total energy has to be used before a material breaks. If the material takes a lot of energy (it may change the shape) before breaking, then it is tough material. It can be determined by calculating index properties related to strength. To study index properties 25 representative bulk samples were prepared in the laboratory. Samples cut into cube shape (length $60 \mathrm{~mm}$ ) were used in determining water absorption, dry density, specific gravity and porosity after ISRM (1979).

Contributions to the weakness of the rock due to the presence of micro cavities should not be overlooked because nearly all rocks, even dense crystalline varieties such as granite, dunite or quartzite, contain microcavities (Sprunt and Brace, 1974). Porosity of the rock samples was calculated by using the following relation.

$$
\text { Porosity }(\mathrm{n})=(\mathrm{Vv} / \mathrm{Vt}) 100(\%) \ldots \ldots . .(1)
$$

Where, $\mathrm{Vv}_{\mathrm{v}}=$ Volume of the void space (such as fluids) and $\mathrm{Vt}=$ Total volume of the sample. Porosity describes how densely the material is packed.

To determine the dry density of the samples the following relation was followed.

$$
\text { Dry density }=\mathrm{Wd} / \mathrm{Vt} \text {. }
$$

Where, $\mathrm{Wd}=$ Dry weight of sample and $\mathrm{Vt}=$ Total volume of the sample.

Aggregate specific gravity is useful in making weight-volume conversions and in calculating the void content in compacted HMA (Roberts et al., 1996). AASHTO M132 and ASTM E12 define specific gravity as:" The ratio of the mass of a unit volume of a material at a stated temperature to the mass of the same volume of gas-free distilled water at a stated temperature." The commonly used "stated temperature" is $23^{\circ} \mathrm{C}$. Specific gravity is calculated by using the given relation.

Specific gravity, $\mathrm{G}=\mathrm{W}_{\mathrm{SSD}} / \mathrm{W}_{\mathrm{S}}$

Where, $\mathrm{W}_{\mathrm{SSD}}=$ saturated surface-dry weight, in grams and $\mathrm{W}_{\mathrm{S}}=$ weight of saturated sample immersed in water, in grams.

Water absorption is an indirect measure of the permeability of an aggregate which, in turn, can relate to other physical characteristics such as mechanical strength, shrinkage, soundness and to its general durability potential. Water absorption percentage is soundness indicator. Absorption limits are rare in British standards, although BS 8007:1987 does include a recommendation that the aggregate absorption should not 'generally' be greater than $3 \%$. The water absorption value above $4 \%$ needs to perform further test on the aggregate to determine its acceptability. The test method of water absorption is accordance to California Test 206 in reference to California test 226, AASTHO T85 and ASTM C127 and 128 (1989). It is determined by measuring the increase in sample weight owing to the pore water expressed as $\%$ of dry weight. In this study, the lump sample (almost cube) having a length of $6 \mathrm{~cm}$ were immersed in water for $24 \mathrm{hrs}$ and water absorption value relative to dry weight was calculated.

The water absorption value was determined by measuring the increase in sample weight owing to pore water, expressed as percentage of dry weight after ASTM C127 and 128 (1989). Water absorption value was calculated by using the following relation:

$$
\mathrm{WA}=\mathrm{B} / \mathrm{A} .100(\%)
$$

Where, $\mathrm{A}=$ oven-dry weight, in grams, and $\mathrm{B}=$ saturated surface-dry weight, in grams

Point load strength test is intended as an index test for the strength classification of rock material. In order to carry out this test, rock specimens in the form of irregular lumps were prepared of each 25 locations. The test procedure was followed after ISRM (2008).

Aggregates undergo substantial wear and tear throughout their life. In general, they should be hard and tough enough to resist crushing, degradation and 
integration from any associated activities including manufacturing, stockpiling, production, placing and compaction (Roberts et al., 1996). Furthermore, they must be able to adequately transmit loads from the pavement surface to the underlying layers. To determine resistance to abrasion of the samples, Los Angeles abrasion test was carried out. Grade A sample was prepared and the procedure of AASHTO T96-77 (1982) was followed. After preparing samples, they were placed in the Los Angeles abrasion testing machine along with 12 steel balls, the machine was then set to revolve 500 revolutions. After completion of the revolutions the steel balls were taken out first and the samples were placed in a tray. The sample was then sieved at $\# 12(1.7 \mathrm{~mm})$, and the retained sample was weighted. The Los Angeles abrasion value (LAAV) was calculated as abrasion loss in percentage as given below:

$$
\operatorname{LAAV}(\%)=(\mathrm{W} 2-\mathrm{W} 1) / \mathrm{W} 1
$$

Where, W1 = Initial weight of the sample, and W2= Original weight of sample after test, coarser than 1.70 $\mathrm{mm}$ sieve.

Toughness controls resistance to impact. Some sources suggest that the effect of impact is greater than that of abrasion (Smith and Collis, 2001). The aggregate samples passing $12.5 \mathrm{~mm}$ sieve and retained on $10 \mathrm{~mm}$ sieve of weight about $400 \mathrm{gm}$ were prepared for this test. The aggregates were filled in a cylinder one-third at a time and tamped 25 times with tamping roads. The process was repeated three times. Test samples were then fixed in position on the base of the machine.

The hammer was raised until its lower face was 38 $\mathrm{cm}$ above the upper surface of aggregates in the cup, and allowed to fall freely on the aggregate. The test samples were subjected to a total of 15 such blows by the $14 \mathrm{Kg}$ weight of hammer, each being delivered at an interval of not less than one second. The crushed aggregate was then removed from the cup and whole of it was sieved on the $2.36 \mathrm{~mm}$ sieve until no further significant amount passes. The mass of an aggregate passing $2.36 \mathrm{~mm}$ sieve was taken for calculation of aggregate impact value (AIV).

$$
\operatorname{AIV}=\left(\mathrm{W}_{2} / \mathrm{W}_{1}\right) 100(\%)
$$

Where, $\mathrm{W}_{1}=$ Total weight of aggregate samples, and $\mathrm{W}_{2}=$ Weight of an aggregate passing through $2.36 \mathrm{~mm}$ sieve.

\section{Soundness}

Some types of rock are in fact strong and resistance to weathering, while others breakdown rather easily over time and have molecular structure and mineral more susceptible to weathering and erosion. To evaluate the resistance to weathering, sodium sulphate soundness test, ethylene glycol soak index and water absorption tests were carried out.

The sodium sulphate soundness test was conducted as per the standard procedure of determining the sulphate soundness of aggregates as ASTM Designation C88-05 (ASTM, 2005). The sulphate soundness value (SSV) was calculated as:

After completion of five cycles (Fig. 3) the samples were washed to free it from the salt, oven dried and hand sieved on the same $10 \mathrm{~mm}$ sieve. Then sthe sodium sulphate soundness value (SSSV) was calculated using the given equation:

$$
\mathrm{SSV}=(\mathrm{W} 1-\mathrm{W} 2) / \mathrm{W} 1.100 \%
$$

Where, W1 = Initial weight of sample, and W2 = Weight retained on $10 \mathrm{~mm}$ sieve after five cycle.

Ethylene glycol has been used to access the durability of rocks which contain swelling clay material. This test employs ethylene glycol which causes rapid expansion of swelling clay materials (Paige-Green, 2004). An ethylene glycol index system of Haskins and Bell (1995) was employed.

\section{RESULTS}

Rockmass of the study area has been described and their parameters have been given in Table 2 and location of the different sample is shown in Fig. 2.

\section{Rock Mass Rating}

Samples from the lower part of the Lower Nawakot Group include mylonite and crenulated phyllite of the Kuncha Formation and quartzite of the Fagfog Quartzite. The rocks are slightly to moderately weathered, thin to thick bedded. Strength of intact rocks 

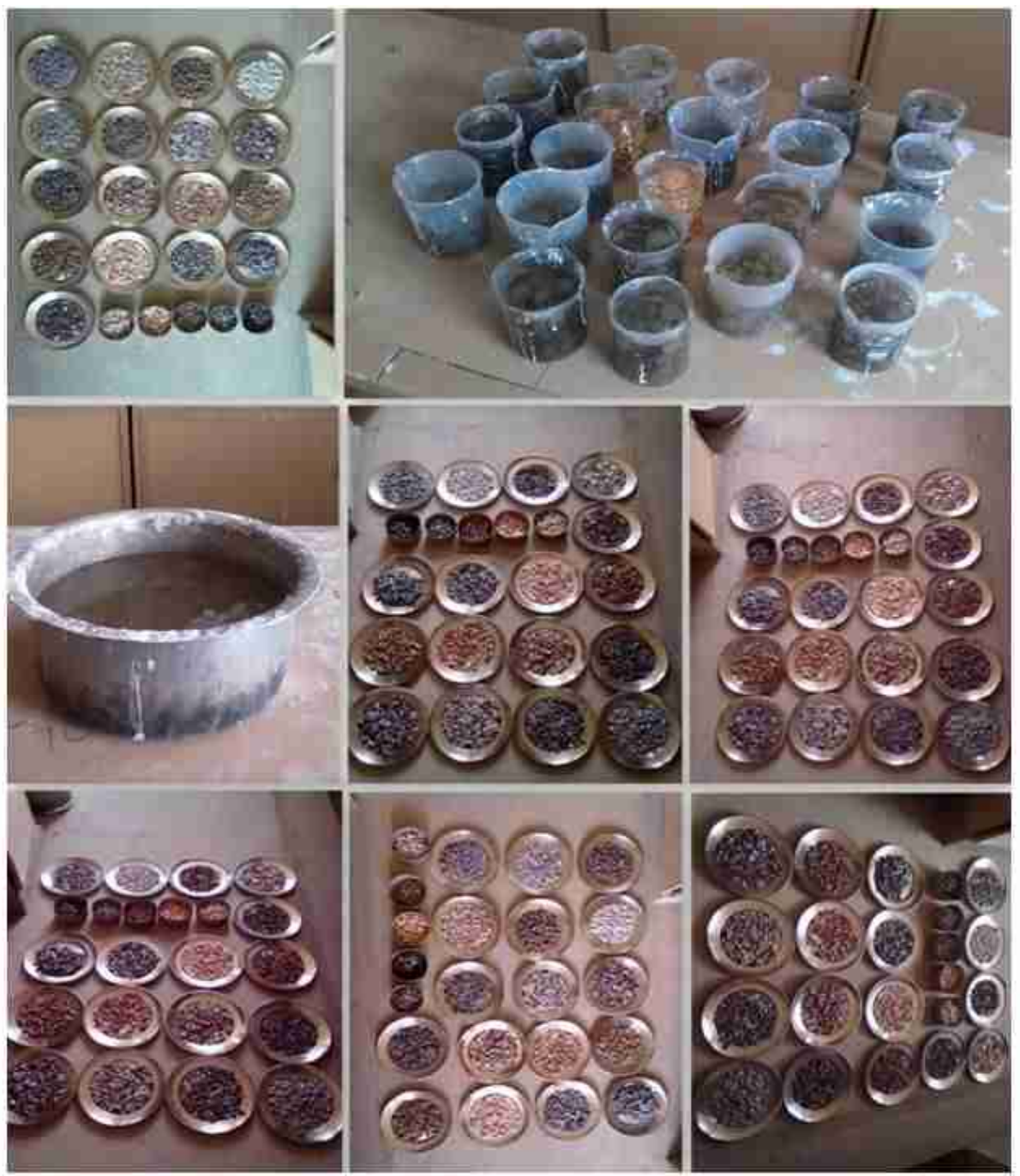

Fig. 3 Samples at different cycles during sodium sulphate soundness test. a) Initial sample before the test, b) Immersion of sample in saturated sodium sulphate, c) Saturated sodium sulphate, d) First cycle, e) Second cycle, f) Third cycle, g) Forth cycle and h) Fifth cycle.

of the area falls between moderately strong to very strong. RQD lies in between fair and excellent. Kn1 and Fg1 have close to moderate spacing of discontinuities whereas $\mathrm{Kn} 2$ and $\mathrm{Fg} 2$ have close to wide spacing of discontinuities. Three to four sets of prominent joint sets are common in all sample sites. Groundwater condition of $\mathrm{Kn} 1$ and $\mathrm{Fg} 2$ is completely dry but condition of $\mathrm{Kn} 2$ and $\mathrm{Fg} 1$ is wet and dry, respectively. With reference to all the parameter of standard RMR classification, RMR value of the area is found between 57 (fair) and 70 (good) (Table 2).

Samples from the upper part of the Lower Nawakot Group include phyllite, quartzite and dolomite of the Dandagoan Phyllite, the Nourpul Formation and Dhading dolomite, respectively. The Dandagoan
Phyllite comprises heavily broken, very poor rock mass. Three to four sets of joints are very common in the sample sites. Strength of intact rocks of the samples sites falls between moderately strong to very strong. RQD of Da1 and Dh1 is very poor but Np1, Np2 and $\mathrm{Np} 3$ have poor to fair RQD. Spacing of discontinuities is medium to close in all samples except $\mathrm{Np} 3$ which has close to wide spacing of discontinuities. Groundwater condition is dry of all sample sites. RMR value of the sample sites ranges from 44 to 64 (Table 2).

Samples from the Upper Nawakot Group include slates of the Benighat Slate, finely crystalline dolomite of the Malekhu Limestone and psammatic schist and quartzite of the Robang Formation. The rockmass condition of sites $\mathrm{Bg} 1$ and $\mathrm{Bg} 2$ is very poor in 
Table 2: Location, lithology and their rock mass rating of the representative samples

\begin{tabular}{|c|c|c|c|}
\hline$\underline{\text { Sample }}$ & Location & Lithology & RMR \\
\hline $\mathrm{Kn} 1$ & $\begin{array}{l}\text { On the uphill side (US) of the Malekhu -Dhading road } \\
\text { about } 1 \mathrm{~km} \text { away from Kalidanda. }\end{array}$ & Grn. grey mylonite and thin bedded metasandstone. & 57 \\
\hline $\mathrm{Kn} 2$ & $\begin{array}{l}\text { Left bank (LB) of the Sukaura Khola, about } 60 \mathrm{~m} \\
\text { upstream from the confluence of it and Thopal Khola. }\end{array}$ & $\begin{array}{l}\text { Thinly laminated greenish gritty phyllite with some } \\
\text { quartz veins. }\end{array}$ & 50 \\
\hline $\mathrm{Fg} 1$ & $\begin{array}{l}\text { US of Malekhu Dhading road } 400 \mathrm{~m} \text { away from } \\
\text { Bairenitar. }\end{array}$ & Coarse grained pink quartzite with ripple marks. & 62 \\
\hline $\mathrm{Fg} 2$ & US of Dhading road, $50 \mathrm{~m}$ toward NE from Dam site. & Coarse-grained, yellowish to light grey orthoquartzite. & 70 \\
\hline Dal & US of Dhading road, just below the Dam site. & Dark grey, graphitic phyllite and quartzite & 44 \\
\hline $\mathrm{Np} 1$ & $\begin{array}{l}\text { Right uphill side (RUS), of Dhading road about } 500 \mathrm{~m} \\
\text { away from Katledada. }\end{array}$ & $\begin{array}{l}\text { White, coarsed -grained siliceous dolomite with thin } \\
\text { partings of chlorite phyllite. }\end{array}$ & 52 \\
\hline $\mathrm{Np} 2$ & $\begin{array}{l}\text { US of Dhading road, } 30 \mathrm{~m} \text { toward Malekhu from Mawi } \\
\text { Khola. }\end{array}$ & $\begin{array}{l}\text { Dark grey finely crystalline quartzite with thinly } \\
\text { foliated greenish grey phyllite. }\end{array}$ & 49 \\
\hline $\mathrm{Np} 3$ & $\begin{array}{l}\text { LS of Thopal the River about } 20 \mathrm{~m} \text { away from the Thopal } \\
\text { bridge. }\end{array}$ & $\begin{array}{l}\text { Coarsed-grained, yellowish grey quartzite intercalated } \\
\text { with greenish grey chlorite, sericite phyllite }\end{array}$ & 64 \\
\hline Dh1 & $\begin{array}{l}\text { On the uphillside of Dhading Highway towards Dhading } \\
\text { Besi. }\end{array}$ & Light grey, thinly laminated, planar dolomite. & 52 \\
\hline Bg1 & $\begin{array}{l}\text { On the uphillside of Dhading Highway towards Dhading } \\
\text { Besi. }\end{array}$ & $\begin{array}{l}\text { Intercalation of planar, thinly laminated grey } \\
\text { calcareous slate. }\end{array}$ & 38 \\
\hline Bg2 & $\begin{array}{l}\text { At the right bank of Trisuli River, near the Suspension } \\
\text { Bridge. }\end{array}$ & $\begin{array}{l}\text { Dark grey, fine grained, calcareous, laminated slate } \\
\text { with some quartz lenses. }\end{array}$ & 36 \\
\hline M11 & $\begin{array}{l}\text { At the left bank of Malekhu Khola, about } 100 \mathrm{~m} \text { upstream } \\
\text { from Malekhu Bridge. }\end{array}$ & $\begin{array}{l}\text { Laminated, planar, finely crystalline dark grey } \\
\text { dolomite. }\end{array}$ & 57 \\
\hline $\mathrm{Ml} 2$ & $\begin{array}{l}\text { At the right bank of Malekhu Khola, about } 50 \mathrm{~m} \text { upstream } \\
\text { from Malekhu Bridge. }\end{array}$ & Finely crystalline, planar, dark grey dolomite. & 57 \\
\hline $\mathrm{Rb} 1$ & $\begin{array}{l}\text { At the left bank of Malekhu Khola, about } 250 \mathrm{~m} \\
\text { downstream from the confluence of Malekhu khola and } \\
\text { Dhobi Khola. }\end{array}$ & $\begin{array}{l}\text { Medium to coarsely crystalline, foliated, planar, dark } \\
\text { grey to white, psammatic schist. }\end{array}$ & 57 \\
\hline $\mathrm{Rb} 2$ & $\begin{array}{l}\text { LB of the Malekhu Khola, } ~ 375 \mathrm{~m} \text { downstream from the } \\
\text { confluence of Malekhu khola and Dhobi Khola. }\end{array}$ & $\begin{array}{l}\text { Grey quartzite intercalated with greenish grey schist } \\
\text { with quartz veins. }\end{array}$ & 45 \\
\hline $\mathrm{Rb} 3$ & $\begin{array}{l}\text { LB of the Malekhu Khola, about } 750 \mathrm{~m} \text { upstream from } \\
\text { Malekhu Bridge. }\end{array}$ & $\begin{array}{l}\text { White sericitic quartzite with thin sericitic parting with } \\
\text { chlorite schist. }\end{array}$ & 66 \\
\hline $\operatorname{Rd} 1$ & $\begin{array}{l}\text { RB of the Malekhu Khola, at the confluence of the } \\
\text { Malekhu Khola and the Dhobi Khola. }\end{array}$ & Greenish grey, biotite present garnetiferous schist. & 60 \\
\hline $\mathrm{Rd} 2$ & $\begin{array}{l}\text { At the left bank of the Malekhu Khola about } 700 \text { m away } \\
\text { from Amiltar. }\end{array}$ & $\begin{array}{l}\text { Greenish grey, medium grained garnetiferous schist } \\
\text { with frequent quartz lenses. }\end{array}$ & 50 \\
\hline Bd1 & At the left bank of Malekhu River, scarp slope. & Coarsely crystalline,wavy, white colored marble & 44 \\
\hline Ka1 & $\begin{array}{l}\text { At the left bank of Malekhu Khola about } 600 \mathrm{~m} \text { away } \\
\text { from Bhuttar. }\end{array}$ & $\begin{array}{l}\text { Intercalation of micaceous schist with fine crystalline } \\
\text { dark grey medium grained quartzite. }\end{array}$ & 39 \\
\hline Ch1 & $\begin{array}{l}\text { At the right bank of Malekhu Khola } 750 \mathrm{~m} \text { away from } \\
\text { Chhepan. }\end{array}$ & Light grey, planar, quartzite with thin parting of schist. & 58 \\
\hline Kh1 & $\begin{array}{l}\text { RB of the Malekhu Khola about } 650 \mathrm{~m} \text { away from } \\
\text { Cheppan. }\end{array}$ & Dark grey biotite schist with few bands of migmatites. & 47 \\
\hline $\mathrm{Kh} 2$ & $\begin{array}{l}\text { RB of the Malekhu Khola about } 600 \mathrm{~m} \text { away from } \\
\text { Chhepan. }\end{array}$ & Massive augen gneiss. & 82 \\
\hline Kh3 & $\begin{array}{l}\text { LB of the Malekhu Khola, about } 20 \mathrm{~m} \text { upstream from } \\
\text { Malekhu Bridge. }\end{array}$ & $\begin{array}{l}\text { Dark grey medium grained biotite schist intercalated } \\
\text { with some light grey quartzite. }\end{array}$ & 59 \\
\hline Ti1 & $\begin{array}{l}\text { RB of the Malekhu Khola about } 50 \mathrm{~m} \text { downstream from } \\
\text { the confluence of Malekhu Khola and stream from } \\
\text { Alegau. }\end{array}$ & $\begin{array}{l}\text { Dark grey, planar, thinly laminated, biotite rich } \\
\text { metasiltstone. }\end{array}$ & 49 \\
\hline
\end{tabular}


comparison to others sites. RQD of other sampled sites is between poor to good. Spacing of discontinuities is wide to very close. RMR value ranges from 36 (poor) to 66 (good) (Table 2). Due to presence of very jointed rock masses and damp to dripping groundwater condition, the RMR of $\mathrm{Bg} 1$ and $\mathrm{Bg} 2$ is very low, 38 and 36 respectively. RMR value of M11 and M12 is equal.

Samples from the lower part of the Bhimphedi Group comprise garnetiferous schist of the Raduwa Formation, coarsely crystalline marble of the Bhaisedobhan Marble, micaceous schist of the Kalitar Formation and quartzite of the Chisapani Quartzite. Strength of intact rocks of all the sampled sites is strong except Ka1 which has medium strength. RQD of Rd1 is excellent. Bd1 is poor whereas Rd2, Ka1 and Ch1 are fair. Three to four sets of joints are very common in the sample sites. Spacing of discontinuities is wide to close. Groundwater condition is dripping to completely dry. RMR value of the sampled site ranges from 39 to 66 . The main reason behind low RMR (39) value of Ka1 is its groundwater condition. Rockmass condition of Rd1, $\mathrm{Rd} 2, \mathrm{Bd} 1$ and $\mathrm{Ch} 1$ is fair with RMR value 60, 50, 44 and 58 , respectively.

Samples from the upper part of the Bhimphedi Group and the lower part of the Phulchoki Group include biotite schist of site Kh1 and Kh3 and augen gneiss (Kh2) of the Kulekhani Formation and metasiltstone (Ti1) of the Tistung Formation. Strength of the intact rock range from strong to extremely strong. RQD is very poor to Excellent. Spacing of the discontinuities is moderate to very close. Groundwater condition is wet to completely dry. RMR value ranges from fair to very good. Considering all the parameters, RMR value of Kh2 is found highest (82) of all the sampled site whereas rockmass conditions of Kh1, Kh3 and Ti1 ares fair with RMR value 47, 59 and 49, respectively.

\section{Durability of Rock Aggregates}

Aggregates are exposed to a number of physical and chemically degrading forces during processing, transporting, and construction. Hence aggregates must be clean, hard, sound, durable, resistant to abrasion, uniform in quality and free of any detrimental quantities of soft, friable, thin, elongated or laminated pieces, disintegrated material, and deleterious substances.

\section{Toughness}

Toughness indicates how much energy a material can absorb before rupturing. It can be defined as the ability of a material to absorb shock without breaking or shattering. All hard materials are not tough. In order to be tough a material must be strong and ductile. Aggregates which lack adequate toughness and abrasion resistance may cause construction and performance problems. Toughness of the rock aggregates can be accessed via index properties related to strength and resistance.

\section{Index properties related to strength}

Results of specific gravity, dry density, and porosity are shown in the Table 2 and that of point load index strength is given in the Table 3 . Porosity is very important indicators for the utilization of various kinds of rocks (Christensen et al., 1996). Porosity of calcareous slate $\mathrm{Bg} 2(8.91 \%)$ is greatest among all the samples whereas smallest is $0.04 \%$ of Kh1 (Table 2). Porosity of low-grade metamorphic rock samples studied is comparatively more than that of other quartzite, schist and gneiss.

Dry density of aggregates used in construction is 2-3 $\mathrm{g} / \mathrm{cm}^{3}$ and average value is about $2.6 \mathrm{~g} / \mathrm{cm}^{3}$ used in road construction (ASTM, 1994). The dry density of Bg2 is lowest, i.e., $2.30 \mathrm{~g} / \mathrm{cm}^{3}$ and highest is of $\mathrm{Kn} 2$, i.e. 3.22 $\mathrm{g} / \mathrm{cm}^{3}$. Since density is not only the single parameter to determine the usage of the aggregates, the same rock has to perform better in all other physical and chemical test in order to use it for different construction purposes.

Specific gravity of all the rock is found to be in between the range of 2.08 to 3.08. The proportion of water absorbed by aggregate determines how much liquid the aggregate can absorb when soaked in water. As the porosity of $\mathrm{Bg} 2(8.91 \%)$ is greatest among all the samples, its WAV is also greatest (4.75\%). Similarly, porosity of $\mathrm{Kh} 1(0.08 \%)$ is smallest as a result WAV is also the smallest $(0.04 \%)$. Water absorption value of most of the rock is found less than $1 \%$ (Table 2). It means most of the rock of the area is less porous. The absorption value greater than $3 \%$ is not recommended for concrete aggregate and road construction (ASTM, 1989). So the rocks of location $\mathrm{Bg} 1$ and $\mathrm{Bg} 2$ are not suggested to use in concrete aggregate. WAV of low grade metamorphic rocks and slate is comparatively 
Table 2: Determination of Specific Gravity, porosity, water absorption value and dry density

\begin{tabular}{|c|c|c|c|c|}
\hline Sample & $\begin{array}{l}\text { Specific } \\
\text { Gravity }\end{array}$ & $\begin{array}{c}\text { Dry } \\
\text { density } \\
\left(\mathrm{g} / \mathrm{cm}^{3}\right)\end{array}$ & $\begin{array}{c}\text { Porosity } \\
(\%)\end{array}$ & $\begin{array}{c}\text { Water } \\
\text { Absorption } \\
\text { Value (\%) }\end{array}$ \\
\hline $\mathrm{Kn} 1$ & 2.69 & 2.73 & 0.94 & 0.53 \\
\hline $\mathrm{Kn} 2$ & 3.08 & 3.22 & 1.59 & 1.42 \\
\hline $\mathrm{Fg} 1$ & 2.7 & 2.73 & 0.57 & 0.32 \\
\hline $\mathrm{Fg} 2$ & 2.57 & 2.64 & 0.87 & 0.9 \\
\hline Da1 & 2.68 & 2.7 & 0.46 & 0.27 \\
\hline Np1 & 2.79 & 2.82 & 0.67 & 0.47 \\
\hline Np2 & 2.68 & 2.73 & 0.85 & 0.64 \\
\hline Np3 & 2.81 & 2.85 & 0.43 & 0.56 \\
\hline Dh1 & 2.75 & 2.81 & 1.32 & 0.86 \\
\hline $\mathrm{Bg} 1$ & 2.22 & 2.49 & 8.55 & 4.73 \\
\hline $\mathrm{Bg} 2$ & 2.08 & 2.3 & 8.91 & 4.75 \\
\hline Ml1 & 2.75 & 2.79 & 0.87 & 0.6 \\
\hline M12 & 2.81 & 2.82 & 0.19 & 0.12 \\
\hline $\mathrm{Rb} 1$ & 2.59 & 2.63 & 0.42 & 0.53 \\
\hline $\mathrm{Rb} 2$ & 2.66 & 2.67 & 0.24 & 0.15 \\
\hline $\mathrm{Rb} 3$ & 2.62 & 2.64 & 0.39 & 0.25 \\
\hline $\mathrm{Rd} 1$ & 2.72 & 2.76 & 0.79 & 0.43 \\
\hline $\mathrm{Rd} 2$ & 2.7 & 2.71 & 0.24 & 0.17 \\
\hline $\mathrm{Bd} 1$ & 2.95 & 2.97 & 0.76 & 0.26 \\
\hline Ka1 & 2.67 & 2.73 & 1.45 & 0.86 \\
\hline Ch1 & 2.65 & 2.66 & 0.32 & 0.22 \\
\hline Kh1 & 2.66 & 2.66 & 0.08 & 0.04 \\
\hline Kh2 & 2.54 & 2.63 & 2.35 & 1.34 \\
\hline Kh3 & 2.62 & 2.67 & 0.97 & 0.72 \\
\hline Ti1 & 2.67 & 2.72 & 0.85 & 0.75 \\
\hline L7 & 2.94 & 3 & 0.74 & 0.49 \\
\hline
\end{tabular}

more than that of other quartzite, schist and gneiss.

\section{Point load strength index}

For aggregate, rock strength uniaxial compressive strength (UCS) value $>100 \mathrm{Mpa}$ is required. The point load index value of different lump samples were measured in a laboratory. The result comparing standard value (Bieniawski, 1975) is given in Table 3. The result of point load index value and UCS is lowest at the Benighat slate $(\mathrm{Bg} 2)$ which was calculated to be 0.26 $\mathrm{MPa}$ and 5.9 $\mathrm{MPa}$, respectively. Similarly, the highest value of point load index and UCS is found at the Robang quartzite (Rb1) which was calculated to be
Table 3: Intact rock strength classification (Bieniawski, 1975)

\begin{tabular}{ccc}
\hline UCS (MPa) & Strength classes & Sample number \\
\hline$>200$ & Very high strength & $\mathrm{Rb} 1$ \\
$100-200$ & High strength & $\mathrm{Fg} 1, \mathrm{Fg} 2, \mathrm{Da} 1, \mathrm{M} 11$, \\
& & $\mathrm{Rd} 2, \mathrm{Ka} 1, \mathrm{Ch} 1$, \\
& & $\mathrm{Kh} 1, \mathrm{Kh} 3$ \\
$50-100$ & Medium strength & $\mathrm{Kn} 1, \mathrm{~Np} 2, \mathrm{~Np} 3$, \\
& & $\mathrm{Rb} 3, \mathrm{Rd} 1$ \\
$25-50$ & Low strength & $\mathrm{Bg} 1, \mathrm{M} 12, \mathrm{Rb} 2$, \\
& & $\mathrm{Bh} 1, \mathrm{Ti} 1$ \\
$<25$ & Very low strength & $\mathrm{Kn} 2, \mathrm{~Np} 1, \mathrm{Dh} 1$, \\
& & $\mathrm{Bg} 2, \mathrm{Kh} 2, \mathrm{~L} 7$ \\
\hline
\end{tabular}

13.13 $\mathrm{MPa}$ and 301.9 $\mathrm{MPa}$, respectively (Table 4)

The rocks can be classified into five classes according to the intact rock strength classification given by Bieniawski (1975).

\section{Resistance to Abrasion}

Hardness (wearing property) and toughness (breaking property) of aggregates associated together are often carried out in Los Angeles test. The principle of the test is to obtain percent wear due to relative rubbing action between aggregates and steel balls used as an abrasive charge. Uniform factor and wear of gravel are determined by Los Angeles test (ASTM 1989). Results of Los Angeles test is shown in the Table 5 .

The samples from 5 different locations were prepared in order to carry out Los Angeles abrasion test. The Los Angles abrasion values of the samples ranges from $19.6 \%$ to $47.5 \%$. Though the sample $\mathrm{Fg} 1$ is quartzite, it has high abrasion loss percentage. Fg1 might have several non-connected pores and weak interlocking, hence couldn't bear impact load and abrasion. Np1 has low UCS but is less porous $(0.67 \%)$ and has low water absorption value $(0.47 \%)$ as well which could be the reason behind the low abrasion.

\section{Resistance to Impact}

The aggregate impact value is expressed as percentage by mass passing $2.36 \mathrm{~mm}$ sieve relative to the original mass. Aggregate Impact Value (AIV) below 10 percent is regarded as strong and AIV above 35 percent is normally regarded as too weak for use in road 
surface. The result of AIV of different rock samples is given in the Table 6 .

The result of AIV ranges from 8.54 to $34.28 \%$ (Table 6). Impact Value (AIV) below 10 percent are regarded as strong and AIV above 35 percent would normally be regarded as too weak for use in road surface (ASTM, 1981). Hence, the rocks of Fg2, Da1, Np2, Np3, Ml1, $\mathrm{M} 12, \mathrm{Rb} 2, \mathrm{Rd} 2, \mathrm{Bd} 1, \mathrm{Ka} 1, \mathrm{Ch} 1$ and $\mathrm{Kh} 1$ are strong and resistant enough to withstand repeated and sudden impact load. Some are satisfactory whereas others are weak for pavement. Only the sample $\mathrm{Np} 1$ and $\mathrm{Rb} 1$ are found exceptionally strong. Sample Rb1 has low WAV $(0.53 \%)$, high UCS $(301.9 \mathrm{MPa})$ and is less porous $(0.79 \%)$ which could be the reason behind such a low AIV whereas, sample Kh2 has very low UCS (19.2 MPa), comparatively high WAV (1.34\%) and more porous $(2.35 \%)$, which leads it to have such a high AIV as well. Impact loss of quartzite and dolomite samples seem to be low than others samples but loss of sample $\mathrm{Fg} 1, \mathrm{Dh} 1$ and $\mathrm{Rb} 3$ is unexpectedly more. The reason behind high loss could be weak interlocking and nonconnected pores.

\section{Soundness}

Soundness test is a measure of how resistant an aggregate is to chemical weathering.

\section{Sodium sulphate soundness value (SSSV)}

Soundness test determines the resistance to disintegration of aggregates due to alternate cycles of dry and wet condition. The result of sodium sulphate soundness value (SSSV) with weight loss in each cycle along with the ratio of weight loss in first to last cycle is given in the Table 7 and Figs. 4 and 5. The percent loss after the five cycles is higher in $\mathrm{Kn} 1, \mathrm{Bg} 2$ and $\mathrm{Kh} 2$ compared to other samples (Fig. 4). Based on behaviour by percent loss of sample due to weathering in sulphate test, roughly four types of samples have been distinguished (Fig. 5).

(i) Samples showing gradual decrease in loss, i.e., initial high loss and low loss at the end of the cycle (Fig. 5a),

(ii) Samples showing more or less constant and negligible loss (Fig. 5b),

(iii) Samples showing high loss at the mid of the cylcle (Fig. 5c), and

(iv) Samples showing fluctuating high and low loss (Fig. 5d).

The result of test samples varies from $1.35 \%$ to $23.66 \%$. The value below $12 \%$ is chemically sound (DOR, 2001 and NS: 297-1994) and above 10\% is chemically unsound (ASTM C33, 1994). Np1 has low UCS but is less porous (0.67\%) and has low water absorption value $(0.47 \%)$ which could be the reason behind the low SSSV. Similarly, augen gneiss sample of the Kulekhani Formation (Kh2) has very low UCS (19.2 MPa), very high AIV (34.28\%), comparatively high WAV (1.34\%) and more porous (2.35\%). Consequently, the sample Kh2 has very high SSSV too.

\section{Ethylene Glycol soaking test}

All the 25 lump samples were soaked for 30 days in the Ethylene Glycol solution and inspected after 1, 5, 10 and 20 days and the number (and location in the tray) of pieces of spalled (shed small fragments from their edges), fractured (split into two or three pieces) and disintegrated (spilt into more than 3 pieces) aggregate were recorded at each assessment but not any kinds of obvious effects were noticed within these periods. Hence, both the class value of the degree of disintegration and class value of time taken to develop the worst condition is 1 . As a result soak test index becomes 2 for all the samples tested. Such types of results could be due to low proportion of swelling clays or due to low accessibility of ethylene glycol through the specimens due to low porosity. Therefore the samples are highly resistant to degradation.

Table 8 lists the specified values for various tests. Table 9 lists samples versus their suitability towards end-uses of construction aggregates.

\section{DISCUSSIONS}

The Lesser Himalaya of the central Nepal is mainly composed of sedimentary and metamorphic rocks. The wide range of metamorphic rock types is reflected in their variable usefulness as aggregate. Coarse- or medium-grained, massive, granular rocks such as quartzites, gneisses and marbles generally provide high quality aggregates, whereas foliated and platy rocks 
Table 4: Determination of point load strength index (Is) and uniaxial compressive strength (UCS)

\begin{tabular}{|c|c|c|c|c|c|c|c|c|c|c|c|c|c|}
\hline Sample & $\begin{array}{c}\mathrm{W}_{1} \\
(\mathbf{m m})\end{array}$ & $\begin{array}{c}\mathbf{W}_{2} \\
(\mathbf{m m})\end{array}$ & $\begin{array}{c}\mathbf{W} \\
(\mathbf{m m})\end{array}$ & $\begin{array}{c}\mathrm{D} \\
(\mathbf{m m}) \\
\end{array}$ & $\begin{array}{c}\mathbf{A} \\
\left(\mathrm{mm}^{2}\right) \\
\end{array}$ & $\begin{array}{c}\mathrm{De}^{2} \\
\left(\mathrm{~mm}^{2}\right) \\
\end{array}$ & $\mathbf{P}(\mathrm{KN})$ & $\begin{array}{c}\mathbf{I}_{\mathrm{s}} \\
(\mathbf{K P a}) \\
\end{array}$ & $\begin{array}{c}\text { De } \\
(\mathbf{m m})\end{array}$ & $* \mathbf{F}$ & $+I_{s(50)}$ & \#UCs & $\begin{array}{c}\text { *Strength } \\
\text { Classification }\end{array}$ \\
\hline $\mathrm{Kn} 1$ & 47 & 55 & 51 & 56 & 2856 & 3636 & 10.5 & 2887 & 60.3 & 1.09 & 3.14 & \multicolumn{2}{|c|}{ 72.3 Medium strength } \\
\hline $\mathrm{Kn} 2$ & 45 & 60 & 52.5 & 41 & 2153 & 2741 & 1.75 & 639 & 52.35 & 1.02 & 0.65 & 15 & $\begin{array}{l}\text { Very low } \\
\text { strength }\end{array}$ \\
\hline $\mathrm{Fg} 1$ & 50 & 60 & 55 & 57 & 3135 & 3992 & 19.75 & 4948 & 63.18 & 1.11 & 5.5 & 126 & High strength \\
\hline $\mathrm{Fg} 2$ & 38 & 40 & 39 & 38 & 1482 & 1887 & 13 & 6889 & 43.44 & 0.94 & 6.47 & 149 & High strength \\
\hline Da1 & 58 & 55 & 56.5 & 45 & 2543 & 3237 & 21 & 6487 & 56.9 & 1.06 & 6.88 & 158 & High strength \\
\hline $\mathrm{Np} 1$ & 50 & 56 & 53 & 50 & 2650 & 3374 & 2.35 & 696 & 58.09 & 1.07 & 0.75 & 17.1 & $\begin{array}{l}\text { Very low } \\
\text { strength }\end{array}$ \\
\hline $\mathrm{Np} 2$ & 45 & 55 & 50 & 49 & 2450 & 3119 & 8.8 & 2821 & 55.85 & 1.05 & 2.97 & 68.2 & $\begin{array}{l}\text { Medium } \\
\text { strength }\end{array}$ \\
\hline Np3 & 48 & 54 & 51 & 30 & 1530 & 1948 & 4.5 & 2310 & 44.14 & 0.95 & 2.18 & 50.2 & $\begin{array}{l}\text { Medium } \\
\text { strength }\end{array}$ \\
\hline Dh1 & 50 & 30 & 40 & 55 & 2200 & 2801 & 2.75 & 982 & 52.93 & 1.03 & 1.01 & 23.2 & $\begin{array}{l}\text { Very low } \\
\text { strength }\end{array}$ \\
\hline $\mathrm{Bg} 1$ & 50 & 44 & 47 & 53 & 2491 & 3172 & 6.25 & 1971 & 56.32 & 1.05 & 2.08 & 47.8 & Low strength \\
\hline $\mathrm{Bg} 2$ & 55 & 58 & 56.5 & 62 & 3503 & 4460 & 1 & 224 & 66.78 & 1.14 & 0.26 & 5.9 & $\begin{array}{l}\text { Very low } \\
\text { strength }\end{array}$ \\
\hline Ml1 & 40 & 60 & 50 & 50 & 2500 & 3183 & 18.75 & 5890 & 56.42 & 1.06 & 6.22 & 143 & High strength \\
\hline Ml2 & 49 & 49 & 49 & 52 & 2548 & 3244 & 4.75 & 1464 & 56.96 & 1.06 & 1.55 & 35.7 & Low strength \\
\hline $\mathrm{Rb} 1$ & 52 & 40 & 46 & 32 & 1472 & 1874 & 26.25 & 14006 & 43.29 & 0.94 & 13.13 & 302 & $\begin{array}{l}\text { Very high } \\
\text { strength }\end{array}$ \\
\hline $\mathrm{Rb} 2$ & 47 & 52 & 49.5 & 50 & 2475 & 3151 & 3.75 & 1190 & 56.14 & 1.05 & 1.25 & 28.8 & Low strength \\
\hline $\mathrm{Rb} 3$ & 56 & 55 & 55.5 & 43 & 2387 & 3039 & 7 & 2304 & 55.12 & 1.04 & 2.41 & 55.4 & $\begin{array}{l}\text { Medium } \\
\text { strength }\end{array}$ \\
\hline $\mathrm{Rd} 1$ & 55 & 55 & 55 & 56 & 3080 & 3922 & 9 & 2295 & 62.62 & 1.11 & 2.54 & 58.4 & $\begin{array}{l}\text { Medium } \\
\text { strength }\end{array}$ \\
\hline $\mathrm{Rd} 2$ & 60 & 40 & 50 & 42 & 2100 & 2674 & 12.75 & 4768 & 51.71 & 1.02 & 4.84 & 111 & High strength \\
\hline $\mathrm{Bd} 1$ & 25 & 25 & 25 & 64 & 1600 & 2037 & 4.25 & 2086 & 45.14 & 0.95 & 1.99 & 45.8 & Low strength \\
\hline Ka1 & 55 & 50 & 52.5 & 40 & 2100 & 2674 & 17.5 & 6545 & 51.71 & 1.02 & 6.64 & 153 & High strength \\
\hline Ch1 & 50 & 46 & 48 & 51 & 2448 & 3117 & 19.25 & 6176 & 55.83 & 1.05 & 6.49 & 149 & High strength \\
\hline Kh1 & 52 & 65 & 58.5 & 43 & 2516 & 3203 & 14.25 & 4449 & 56.59 & 1.06 & 4.7 & 108 & High strength \\
\hline $\mathrm{Kh} 2$ & 60 & 65 & 62.5 & 45 & 2813 & 3581 & 2.75 & 768 & 59.84 & 1.08 & 0.83 & 19.2 & $\begin{array}{l}\text { Very low } \\
\text { strength }\end{array}$ \\
\hline $\mathrm{Kh} 3$ & 47 & 52 & 49.5 & 48 & 2376 & 3025 & 14.1 & 4661 & 55 & 1.04 & 4.87 & 112 & High strength \\
\hline Ti1 & 40 & 38 & 39 & 54 & 2106 & 2681 & 3.5 & 1305 & 51.78 & 1.02 & 1.33 & 30.5 & Low strength \\
\hline L7 & 45 & 45 & 45 & 55 & 2475 & 3151 & 1.25 & 397 & 56.14 & 1.05 & 0.42 & 9.6 & $\begin{array}{l}\text { Very low } \\
\text { strength }\end{array}$ \\
\hline
\end{tabular}

Note: $* \mathrm{~F}=(\mathrm{De} / 50)^{\wedge} 0.45,+\mathrm{I}_{\mathrm{s}(50)}=(\mathrm{F} . \mathrm{f}) / 1000(\mathrm{MPa})$ and $\# \mathrm{UCS}=23 . \mathrm{I}_{\mathrm{s}(50)}(\mathrm{MPa})$ 
Table 5: Result of LA test

\begin{tabular}{cccccc}
\hline $\begin{array}{c}\text { Sample } \\
\text { no. }\end{array}$ & $\begin{array}{c}\text { No. of } \\
\text { spheres }\end{array}$ & $\begin{array}{c}\text { No. of } \\
\text { revolution }\end{array}$ & $\begin{array}{c}\text { Total weight of } \\
\text { Specimen, } \\
\mathbf{W}_{\mathbf{1}}(\mathbf{g m})\end{array}$ & $\begin{array}{c}\text { Original weight of sample after the } \\
\text { test retained on 1.7mm sieve, } \mathbf{W}_{\mathbf{2}}\end{array}$ & $\begin{array}{c}\text { *Abrasion } \\
(\mathbf{g m})\end{array}$ \\
\hline Fg1 & 12 & 500 & 5000 & 2625 & 47.5 \\
Np1 & 12 & 500 & 5000 & 4020 & 19.6 \\
Np3 & 12 & 500 & 5000 & 3941 & 21.18 \\
M11 & 12 & 500 & 5000 & 3307 & 33.86 \\
Kh3 & 12 & 500 & 5000 & 3573 & 28.54 \\
\hline
\end{tabular}

Table 6: Determination of aggregate impact value (AIV)

\begin{tabular}{|c|c|c|c|c|c|}
\hline Formation & Sample no. & Rock type & $\begin{array}{l}\text { Total Wt. } \\
\text { W }_{1}(\mathrm{gm})\end{array}$ & $\begin{array}{l}\text { Wt. retained at } 2.36 \mathrm{~mm} \\
\text { sieve } W_{2}(\mathrm{gm})\end{array}$ & *AIV (\%) \\
\hline \multirow[t]{2}{*}{ Kuncha } & Kn1 & Mylonite & 500 & 378.3 & 24.34 \\
\hline & $\mathrm{Kn} 2$ & Phyllite & 500 & 359.6 & 28.08 \\
\hline \multirow[t]{2}{*}{ Fagfog } & $\mathrm{Fg} 1$ & Quartzite & 500 & 399.4 & 20.12 \\
\hline & $\mathrm{Fg} 2$ & Quartzite & 500 & 445.3 & 10.94 \\
\hline Dandagoan & Da1 & Phyllite & 500 & 432 & 13.6 \\
\hline \multirow[t]{3}{*}{ Nourpul } & Np1 & Siliceous Dolomite & 500 & 450.5 & 9.9 \\
\hline & $\mathrm{Np} 2$ & Quartzite & 500 & 441.7 & 11.66 \\
\hline & Np3 & Quartzite & 500 & 447 & 10.6 \\
\hline Dhading dolomite & Dh1 & Dolomite & 500 & 346.4 & 30.72 \\
\hline \multirow[t]{2}{*}{ Benighat slate } & $\mathrm{Bg} 1$ & Slate & 500 & 350.2 & 29.96 \\
\hline & $\mathrm{Bg} 2$ & Slate & 500 & 357.1 & 28.58 \\
\hline \multirow[t]{2}{*}{ Malekhu limestone } & Ml1 & Dolomite & 500 & 445.4 & 10.92 \\
\hline & M12 & Dolomite & 500 & 414 & 17.2 \\
\hline \multirow[t]{4}{*}{ Robang } & $\mathrm{Rb} 1$ & Psammatic Schist & 500 & 457.3 & 8.54 \\
\hline & $\mathrm{Rb} 2$ & Quartzite & 500 & 416.5 & 16.7 \\
\hline & $\mathrm{Rb} 3$ & Quartzite & 500 & 383.7 & 23.26 \\
\hline & L7 & Amphibolite & 500 & 395 & 21 \\
\hline \multirow[t]{2}{*}{ Raduwa } & Rd1 & Schist & 500 & 396.6 & 20.68 \\
\hline & $\mathrm{Rd} 2$ & Schist & 500 & 410.9 & 17.82 \\
\hline Bhainsedovan & $\mathrm{Bd} 1$ & Marble & 500 & 443.4 & 11.32 \\
\hline Kalitar & Ka1 & Schist & 500 & 416.6 & 16.68 \\
\hline Chisapani Quartzite & Ch1 & Quartzite & 500 & 447.6 & 10.48 \\
\hline \multirow[t]{3}{*}{ Kulekhani } & Kh1 & Biotite Schist & 500 & 412.2 & 17.56 \\
\hline & $\mathrm{Kh} 2$ & Augen gneiss & 500 & 328.6 & 34.28 \\
\hline & kh3 & Biotite Schist & 500 & 405.2 & 18.96 \\
\hline Tistung & Ti1 & Metasiltstone & 500 & 382.2 & 23.56 \\
\hline
\end{tabular}


Table 7: Determination of Sodium sulphate soundness value (SSSV)

\begin{tabular}{|c|c|c|c|c|c|c|c|c|c|c|c|c|c|}
\hline \multirow[b]{2}{*}{$\begin{array}{c}\text { Sample } \\
\text { no. }\end{array}$} & \multirow[b]{2}{*}{ Rock type } & \multirow[b]{2}{*}{$\begin{array}{r}\text { Initial } \\
\text { weight } \\
W_{i}(\mathrm{gm})\end{array}$} & \multicolumn{2}{|c|}{ After $1^{\text {st }}$ cycle } & \multicolumn{2}{|c|}{ After $2^{\text {nd }}$ cycle } & \multicolumn{2}{|c|}{ After $3^{\text {rd }}$ cycle } & \multicolumn{2}{|c|}{ After $4^{\text {th }}$ cycle } & \multicolumn{3}{|c|}{ After $5^{\text {th }}$ cycle } \\
\hline & & & $\begin{array}{c}\text { Weight } \\
\text { (gm) }\end{array}$ & $\begin{array}{l}\text { Weight } \\
\text { loss \% }\end{array}$ & $\begin{array}{c}\text { Weight } \\
\text { (gm) }\end{array}$ & $\begin{array}{l}\text { Weight } \\
\text { loss \% }\end{array}$ & $\begin{array}{c}\text { Weight } \\
\text { (gm) }\end{array}$ & $\begin{array}{l}\text { Weight } \\
\text { loss \% }\end{array}$ & $\begin{array}{c}\text { Weight } \\
\text { (gm) }\end{array}$ & $\begin{array}{l}\text { Weight } \\
\text { loss \% }\end{array}$ & $\begin{array}{c}\text { Weight } \\
\text { W }_{\text {f }}(\text { gm) }\end{array}$ & $\begin{array}{l}\text { Weight } \\
\text { loss \% }\end{array}$ & $\begin{array}{c}\text { t } \\
\% \text { SSSV } \\
\%\end{array}$ \\
\hline $\mathrm{Kn} 1$ & Mylonite & 400 & 392.01 & 1.99 & 385 & 1.79 & 383.58 & 0.36 & 377.05 & 1.7 & 372.22 & 1.28 & 7.12 \\
\hline $\mathrm{Kn} 2$ & Phyllite & 400 & 383.72 & 4.04 & 356.2 & 7.17 & 340 & 4.54 & 333.22 & 1.99 & 326.3 & 2.07 & 19.81 \\
\hline $\mathrm{Fg} 1$ & Quartzite & 400 & 382.48 & 4.38 & 377.71 & 1.24 & 375.66 & 0.54 & 373.12 & 0.67 & 370.56 & 0.68 & 7.51 \\
\hline $\mathrm{Fg} 2$ & Quartzite & 400 & 395.88 & 1.03 & 391.22 & 1.17 & 387.69 & 0.9 & 384.02 & 0.94 & 380.65 & 0.87 & 4.91 \\
\hline Da1 & Phyllite & 400 & 391.32 & 2.17 & 385.13 & 1.58 & 381.91 & 0.83 & 380.24 & 0.43 & 377.29 & 0.77 & 5.78 \\
\hline Np1 & $\begin{array}{l}\text { Siliceous } \\
\text { Dolomite }\end{array}$ & 400 & 397.99 & 0.5 & 396.1 & 0.47 & 395.8 & 0.07 & 393.14 & 0.67 & 390.6 & 0.64 & 2.35 \\
\hline $\mathrm{Np} 2$ & Quartzite & 400 & 391.09 & 2.22 & 386.24 & 1.24 & 383.99 & 0.58 & 383.13 & 0.22 & 381.65 & 0.38 & 4.64 \\
\hline Dh1 & Dolomite & 400 & 397.09 & 0.72 & 362.13 & 8.8 & 359.79 & 0.64 & 356.61 & 0.88 & 353.45 & 0.88 & 11.92 \\
\hline $\mathrm{Bg} 1$ & $\begin{array}{c}\text { Calcareous } \\
\text { Slate }\end{array}$ & 400 & 396.12 & 0.97 & 388.94 & 1.81 & 382.21 & 1.73 & 377.34 & 1.27 & 373.32 & 1.06 & 6.84 \\
\hline $\mathrm{Bg} 2$ & $\begin{array}{c}\text { Calcareous } \\
\text { Slate }\end{array}$ & 400 & 396.37 & 0.9 & 376.01 & 5.13 & 351.59 & 6.49 & 329.12 & 6.39 & 320.89 & 2.5 & 21.41 \\
\hline M11 & Dolomite & 400 & 387.89 & 3.02 & 382.55 & 1.37 & 382.01 & 0.14 & 372.12 & 2.58 & 370.13 & 0.53 & 7.64 \\
\hline M12 & Dolomite & 400 & 399.32 & 0.17 & 389.49 & 2.46 & 379.71 & 2.51 & 374.73 & 1.31 & 370.74 & 1.06 & 7.51 \\
\hline $\mathrm{Rb} 1$ & $\begin{array}{l}\text { Psammatic } \\
\text { Schist }\end{array}$ & 400 & 393.19 & 1.7 & 391.5 & 0.42 & 390.15 & 0.34 & 385.22 & 1.26 & 380.82 & 1.14 & 4.86 \\
\hline $\mathrm{Rb} 2$ & Quartzite & 400 & 392.81 & 1.79 & 386.77 & 1.53 & 385.32 & 0.37 & 380.36 & 1.28 & 378.31 & 0.53 & 5.5 \\
\hline $\mathrm{Rb} 3$ & Quartzite & 400 & 385.15 & 3.71 & 370.81 & 3.72 & 365.68 & 1.38 & 363.24 & 0.66 & 358.71 & 1.24 & 10.71 \\
\hline $\mathrm{Rd} 1$ & Schist & 400 & 396.01 & 0.99 & 387.91 & 2.04 & 386.03 & 0.48 & 378.87 & 1.85 & 372.52 & 1.67 & 7.03 \\
\hline $\mathrm{Bd} 1$ & Marble & 400 & 385.91 & 3.52 & 373.62 & 3.18 & 369.22 & 1.18 & 361.65 & 2.05 & 357.21 & 1.22 & 11.15 \\
\hline Ka1 & Schist & 400 & 398.29 & 0.42 & 397.46 & 0.2 & 388.31 & 2.3 & 381.81 & 1.67 & 373.23 & 2.24 & 6.83 \\
\hline Ch1 & Quartzite & 400 & 393.01 & 1.74 & 388.86 & 1.05 & 383.98 & 1.25 & 380.33 & 0.95 & 377.32 & 0.79 & 5.78 \\
\hline Kh1 & Schist & 400 & 378.68 & 5.33 & 370.41 & 2.18 & 367.92 & 0.67 & 364.35 & 0.97 & 361.64 & 0.74 & 9.89 \\
\hline $\mathrm{Kh} 2$ & Augen gneiss & s 400 & 359.84 & 10.04 & 342.8 & 4.73 & 322.58 & 5.89 & 316.34 & 1.93 & 305.36 & 3.47 & 26.06 \\
\hline Ti1 & Metasiltstone & e 400 & 392.27 & 1.93 & 389.02 & 0.82 & 383.42 & 1.43 & 372.21 & 2.98 & 365.88 & 1.7 & 8.86 \\
\hline
\end{tabular}

such as schist and phyllites are usually weaker and are less durable. Sedimentary rocks such as limestones and dolomites are hard and durable for aggregates. They are common rock types and usually occur in thick beds which are structurally simple and easy to quarry. As a consequence, they are widely extracted for aggregates materials, as well as for cement manufacture (limestone only), and for industrial processes which utilize the chemical properties of the stone (Harrison, 1992).

Mylonite and phyllite samples were collected from the Kuncha Formation and phyllite sample from the 


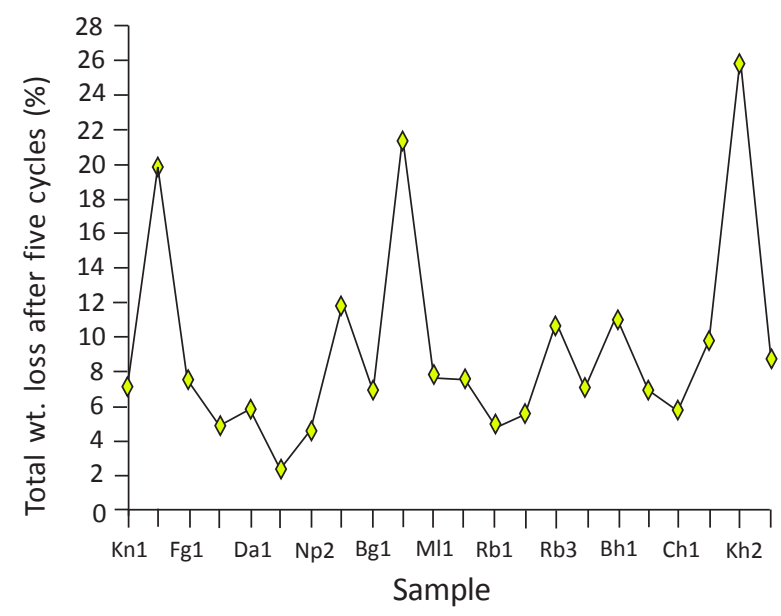

Fig. 4 Graphical representation of total weight loss of each sample after sodium sulphate soundness test.

Dandagaon Phyllite. Samples Kn1 and Kn2 resemble each other in most of the test performed except in UCS and SSSV. UCS and SSSV of Kn1 is far more better than that of Kn2. But if the phyllites of the Kuncha Formation and the Dandagoan Phyllites are compared then the performance of the Dandagoan Phyllite is better than that of the Kuncha phyllite in every test conducted. Porosity of $0.46 \%$, UCS of $158.1 \mathrm{MPa}$, AIV of $13.6 \%$, WAV of $0.27 \%$ and SSSV of $5.78 \%$ added more effectiveness towards toughness and soundness to the phyllite of the Dandagoan Phyllite.

Dolomite samples were collected from the Nourpul Formation, the Malekhu Limestone and the Dhading dolomite. UCS of Dh1 is 23.2 MPa whereas those of M11 and M12 are high. AIV and SSSV of Dh1 are higher than that of Ml1 and Ml2. With reference to the performance of samples, it can be concluded that the Malekhu Limestone is better in every respect than the Dhading Dolomite.

Altogether seven quartzite samples were collected and tested. If the quartzite samples from the Fagfog Quartzite are compared then the performance of both the samples is found almost same in every test except in impact test. Though the quartzite sample Fg1 has very good UCS but didn't performed well in impact test and abrasion test, sample $\mathrm{Fg} 2$ can be considered superior than Fg1. Al-Harthi (2001) tested Saudi Arabian rocks and correlated LA abrasion loss with both UCS and point load index. He showed that LA abrasion loss

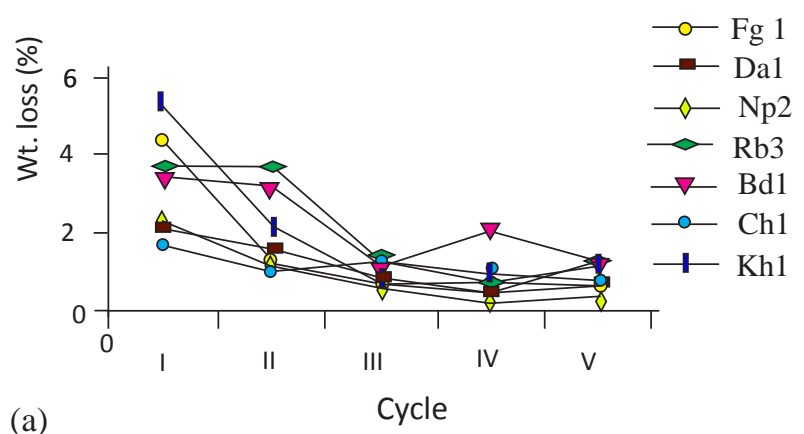

(a)
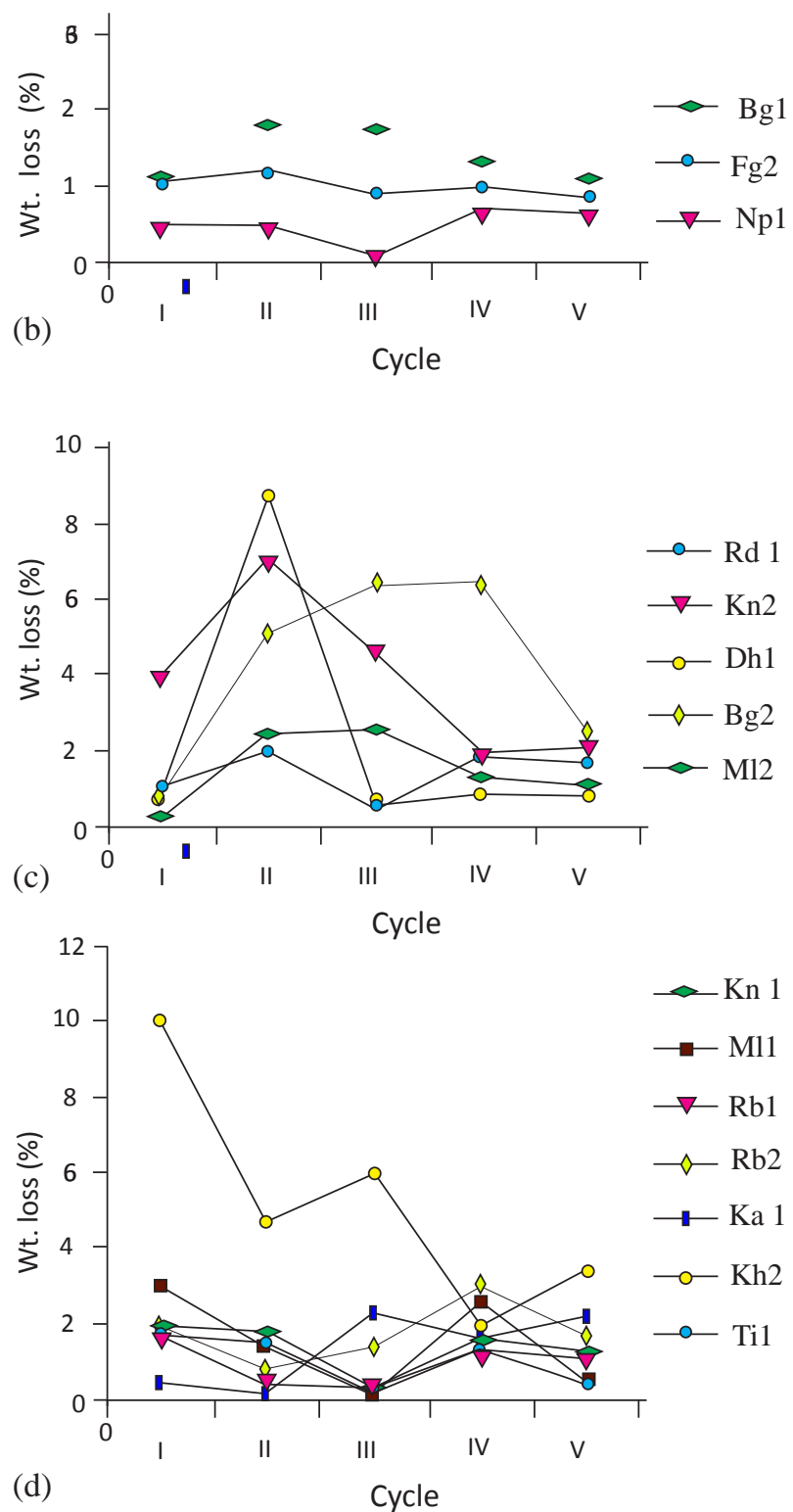

Fig 5: Weight loss behavior of degradation in each cycle during sodium sulphate soundness test. a) Curves of samples Fg1, Da1, $\mathrm{Np2}, \mathrm{Rb} 3, \mathrm{Bd} 1, \mathrm{Ch} 1$ and Kh1, b) Curves of samples Bg1, Fg2, and Np1, c) Curves of samples Rd1, Kn2, Dh1, Bg2 and M12 and d) Curves samples of Kn1, Ml1, Rb1, Rb2, Ka1, Kh2 and Ti1 
Table 8: Specifications of Various tests

\begin{tabular}{ll}
\hline Standards & Description \\
\hline \multicolumn{2}{c}{ Water absorption value } \\
ASTM C 128/127 & $\begin{array}{l}\text { Generally, <2\%, Not more than 2\% } \\
\text { for Riprap } \\
\text { AASTHO H 85 }\end{array}$ \\
Generally, <5\% \\
Generally, <3\%, 2\% for roadstone \\
aggregate. Not usually limited, but a \\
recommended max. value of 2.5\% is \\
sometimes specified for concrete \\
aggregate and less than 3\% for filter \\
aggregates.
\end{tabular}

\section{Specifications of Sodium sulphate soundness test}

ASTM C33, 1994 Above $10 \%$ is chemically unsound $10 \%$ loss at 5 cycle (PCC, Asphalt),

$12 \%$ loss at 5 cycle (surfacing and foundation courses), Armour coat

AASHTO T $104<5 \%$

\section{Specifications of AIV}

ASTM, $1979<10 \%$ (Exceptionally strong), 10-20\% (Strong), 20-30\% (Satisfactory for pavement surfacing) and $>35 \%$

(Weak for pavement)

NS: 297-1994 $<40 \%$ for wearing surface and $<45 \%$ for normal concrete

BS 882: $1983<25 \%$ for heavy-duty concrete floor finishes, $<30 \%$ for concrete pavement wearing surfaces and $<45 \%$ in other concrete

Los Angeles Abrasion Value

\begin{tabular}{cl} 
AASHTO T 96 & $<40 \%$ for PCC and bituminous \\
ASTM C 131 & $<30 \%$ for Bituminous mix, $<50 \%$ for \\
& base course and $<16 \%$ for PCC \\
NS: 297-1994 & $<30 \%$ for Road and concrete \\
& structures, and $<45 \%$ for others \\
DOR (2001) & $<30-35 \%$ for Base course and $<40 \%$ \\
& for Sub-base; For Bound \\
& MACADAM: $<40 \%$ for Base and \\
& $<45 \%$ for Sub Base \\
\hline
\end{tabular}

decreases with increasing UCS and point load index. Quartzite samples (Np2 and Np3) of the Nourpul Formation performed equally better in almost all the tests. But performance on index tests related to strength is almost same of all the samples. Hence, if the rocks from the Nourpul Formation have to be quarried, then the quartzite of location $\mathrm{Np} 2$ is appropriate. Two quartzite samples of the Robang Formation i.e Rb2 and Rb3 which has met the standards of all the specifications adopted. Hence, after following the standards of different specifications, the samples can be recommended for several construction purposes. With porosity of $0.32 \%$, dry density $2.66 \mathrm{gm} / \mathrm{cm}^{3}$, specific gravity 2.65 , UCS of $149.3 \mathrm{MPa}$, AIV\% and SSSV of $5.78 \%$, Ch1 can be considered as one of the durable rock sample collected from the area. Hence, it can be recommended for different end uses.

Two representative slate samples were collected from the Benighat Slate. Strength of both the slate samples is low. Water absorption value and porosity is greatest among the entire samples. UCS of both the slates is also very low. Amah et al. (2012) studied basement rocks (South-Eastern Nigeria) for construction aggregates and found that moisture content (W\%) increases with decreasing hardness $(\mathrm{H})$, specific gravity (SG) and compressive strength except where rock weathering and underground water cause some adverse effects on the rock quality. A decrease in the compressive strength of rocks could also be attributed to the presence of fractures, joints or microcracks, arising from the geological cause such as pressure relief from erosion, and cementation from circulating ground water (Wang and Simmons, 1978). Weathering and structural defects (fractures/joints/microcracks) generally will decrease the strength of the material, accelerate the rate of alteration and increase the amount of saturation. RMR value of $\mathrm{Bg} 1$ and $\mathrm{Bg} 2$ is also very low i.e. 38 and 36 respectively. Normally, the rock aggregates having such mediocre performance are recommended for limited range of construction work adopting the standards of different specifications.

Altogether six schist samples were collected from the study area, one from the Robang Formation, two from the Raduwa Formation, two from the Kulekhani Formation and only one from the Kalitar Formation. Rb1 seems to be durable with UCS of 301.9 MPa, AIV 
Table 9: Suitability of samples in terms of end-uses. The symbol v marks for suitability.

\begin{tabular}{|c|c|c|c|c|c|c|c|c|c|c|c|c|}
\hline \multirow[b]{2}{*}{ Sample } & \multirow[b]{2}{*}{ Rock type } & \multicolumn{2}{|c|}{ Durability } & \multirow[b]{2}{*}{ 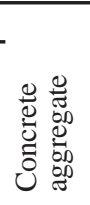 } & \multirow[b]{2}{*}{ 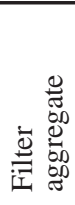 } & \multirow[b]{2}{*}{$\begin{array}{l}0 \\
\tilde{0} \\
\frac{0}{1} \\
\frac{1}{\Xi} \\
\text { ज }\end{array}$} & \multicolumn{5}{|c|}{ Pavement } & \multirow[b]{2}{*}{ 芯 } \\
\hline & & Toughness & Soundness & & & & 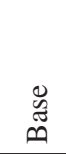 & 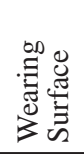 & 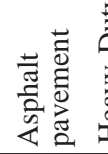 & 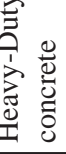 & 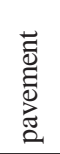 & \\
\hline Kn1 & Mylonite & high & high & $\mathrm{v}$ & $\mathrm{v}$ & & & $\mathrm{v}$ & $\mathrm{v}$ & $\mathrm{v}$ & & \\
\hline $\mathrm{Kn} 2$ & Phyllite & moderate & low & & $\mathrm{v}$ & & & & & & & \\
\hline $\mathrm{Fg} 1$ & Quartzite & very high & high & $\mathrm{v}$ & $\mathrm{v}$ & & $\mathrm{v}$ & $\mathrm{v}$ & $\mathrm{v}$ & $\mathrm{v}$ & & $\mathrm{v}$ \\
\hline $\mathrm{Fg} 2$ & Quartzite & very high & high & $\mathrm{v}$ & $\mathrm{v}$ & & & $\mathrm{v}$ & $\mathrm{v}$ & $\mathrm{v}$ & & $\mathrm{v}$ \\
\hline Da1 & $\begin{array}{l}\text { Phyllite } \\
\text { Siliceous }\end{array}$ & high & high & $\mathrm{v}$ & $\mathrm{v}$ & & & $\mathrm{v}$ & $\mathrm{v}$ & $\mathrm{v}$ & & $\mathrm{v}$ \\
\hline Np1 & Dolomite & moderate & high & $\mathrm{v}$ & $\mathrm{v}$ & $\mathrm{v}$ & $\mathrm{v}$ & $\mathrm{v}$ & $\mathrm{v}$ & $\mathrm{v}$ & & $\mathrm{v}$ \\
\hline $\mathrm{Np} 2$ & Quartzite & very high & high & $\mathrm{v}$ & $\mathrm{v}$ & & & $\mathrm{v}$ & $\mathrm{v}$ & $\mathrm{v}$ & & $\mathrm{v}$ \\
\hline Np3 & Quartzite & very high & high & $\mathrm{v}$ & $\mathrm{v}$ & $\mathrm{v}$ & $\mathrm{v}$ & $\mathrm{v}$ & & $\mathrm{v}$ & & $\mathrm{v}$ \\
\hline Dh1 & Dolomite & moderate & moderate & $\mathrm{v}$ & $\mathrm{v}$ & & & $\mathrm{v}$ & & & & $\mathrm{v}$ \\
\hline $\mathrm{Bg} 1$ & Slate & low & low & & & & & & & & & \\
\hline $\mathrm{Bg} 2$ & Slate & low & low & & & & & & & & & \\
\hline M11 & Dolomite & high & high & $\mathrm{v}$ & $\mathrm{v}$ & $\mathrm{v}$ & $\mathrm{v}$ & $\mathrm{v}$ & $\mathrm{v}$ & $\mathrm{v}$ & & $\mathrm{v}$ \\
\hline M12 & Dolomite & high & high & $\mathrm{v}$ & $\mathrm{v}$ & & & $\mathrm{v}$ & $\mathrm{v}$ & $\mathrm{v}$ & & $\mathrm{v}$ \\
\hline & Psammatic & & & & & & & & & & & \\
\hline $\mathrm{Rb} 1$ & Schist & high & high & $\mathrm{v}$ & $\mathrm{v}$ & & & $\mathrm{v}$ & $\mathrm{v}$ & $\mathrm{v}$ & & $\mathrm{v}$ \\
\hline $\mathrm{Rb} 2$ & Quartzite & high & hgih & $\mathrm{v}$ & $\mathrm{v}$ & & & $\mathrm{v}$ & $\mathrm{v}$ & $\mathrm{v}$ & & $\mathrm{v}$ \\
\hline $\mathrm{Rb} 3$ & Quartzite & high & high & $\mathrm{v}$ & $\mathrm{v}$ & & & $\mathrm{v}$ & $\mathrm{v}$ & $\mathrm{v}$ & & $\mathrm{v}$ \\
\hline $\mathrm{Rd} 1$ & Schist & moderate & high & $\mathrm{v}$ & $\mathrm{v}$ & & & $\mathrm{v}$ & $\mathrm{v}$ & $\mathrm{v}$ & & $\mathrm{v}$ \\
\hline $\mathrm{Rd} 2$ & Schist & moderate & high & $\mathrm{v}$ & $\mathrm{v}$ & & & $\mathrm{v}$ & & $\mathrm{v}$ & & $\mathrm{v}$ \\
\hline $\mathrm{Bd} 1$ & Marble & moderate & moderate & $\mathrm{v}$ & $\mathrm{v}$ & & & $\mathrm{v}$ & $\mathrm{v}$ & $\mathrm{v}$ & & $\mathrm{v}$ \\
\hline Ka1 & Schist & moderate & high & $\mathrm{v}$ & $\mathrm{v}$ & & & $\mathrm{v}$ & $\mathrm{v}$ & $\mathrm{v}$ & & $\mathrm{v}$ \\
\hline Ch1 & Quartzite & moderate & high & $\mathrm{v}$ & $\mathrm{v}$ & & & $\mathrm{v}$ & $\mathrm{v}$ & $\mathrm{v}$ & & $\mathrm{v}$ \\
\hline Kh1 & Biotite Schist & moderate & moderate & $\mathrm{v}$ & $\mathrm{v}$ & & & $\mathrm{v}$ & $\mathrm{v}$ & $\mathrm{v}$ & & $\mathrm{v}$ \\
\hline $\mathrm{Kh} 2$ & Augen gneiss & moderate & moderate & $\mathrm{v}$ & $\mathrm{v}$ & & & $\mathrm{v}$ & & & & $\mathrm{v}$ \\
\hline Kh3 & Biotite Schist & high & high & $\mathrm{v}$ & $\mathrm{v}$ & $\mathrm{v}$ & $\mathrm{v}$ & $\mathrm{v}$ & & $\mathrm{v}$ & & $\mathrm{v}$ \\
\hline Ti1 & Metasiltstone & moderate & moderate & $\mathrm{v}$ & $\mathrm{v}$ & & & $\mathrm{v}$ & $\mathrm{v}$ & $\mathrm{v}$ & & $\mathrm{v}$ \\
\hline
\end{tabular}

of $8.54 \%$ and $4.86 \%$ of SSSV. Rb1 meets the standard of all the specifications followed. Hence, it can be recommended for wide range of construction purposes. Garnetiferous schist of the Raduwa Formation also performed moderately in all the tests conducted. But the performance of garnetiferous schist of site $\mathrm{Rd} 2$ is better than Rd1 in every test.

Marble of the Bhaisedobhan Marble performed well in all test. Porosity of the sample is just $0.76 \%$ which also supported water absorption value. SSSV of the 
samples is also good. Hence, the sample of the Bhaisedobhan could be utilized for several purposes.

The Kulekhani augen gneiss has high strength but high porosity and water absorption value with average specific gravity and dry density. The sample is hard but not tough enough to react under sudden impacts. So, it has high impact loss.

The only sample of the Phulchauki Group was collected for the test of durability is Til of the Tistung Formation. It is an average performer in the all the test. SSSV of $8.86 \%$ supported it in durability but AIV and UCS put it behind other samples. So, the sample Ti1 could be recommended only for fewer end uses.

\section{CONCLUSIONS}

The study area comprises sedimentary and metamorphic rocks. Slate, phyllite, schist, quartzite, marble, and augen gneiss are the metamorphic rocks and dolomite and is the sedimentary rock found in the study area.

Most of the rockmass of the study area is in dry condition but wet and dripping rockmass condition is also common in some rockmass. Three to four major joint sets are common in the area with smooth to rough surface. The rocks of the area are found slightly to moderately weathered, thin to thick bedded with gentle topography. RMR values of the rockmass containing quartzites are comparatively more than the rockmass containing other rock type. RMR value of the study area is found between fair to good. The only augen gneiss sample of the Kulekhani Formation has the excellent RMR value.

Specific gravity ranges from 2.08 to 3.08 and the dry density ranges 2.3 to $3.22 \mathrm{~g} / \mathrm{cm} 3$. All the samples have porosity less than $2 \%$ except the samples of the Benighat Slate. Bg1 and Bg2 have porosity $8.55 \%$ and $8.9 \%$ respectively. UCS value ranges from 5.9 $\mathrm{MPa}$ to 301.9 MPa. Psammatic schist of the Robang Formation has the highest UCS. The LA abrasion percentage is greatest of quartzite the Fagfog Quartzite (Fg2) and lowest of siliceous dolomite of the Nourpul Formation. Aggregate impact value (AIV) of psammatic schist (Rb1) is lowest and highest of augen gneiss (Kh2). With all the results of index properties along with LA test, it can be concluded that the rocks of the area are tough enough to resist the impact load.

The SSSV of three samples Kn2, Bg2 and Kh2 are greater than $12 \%$ hence does not meet the criteria for any end uses. But all other samples are chemically sound and resistance against weathering and frost susceptibility.

WAV of all the samples is below $2 \%$ except Bg1 $(4.73 \%)$ and $\mathrm{Bg} 2(4.75 \%)$, which indicates that the aggregates have low effective porosity.

Ethylene glycol soaking test also shows that proportion of swelling clays and accessibility through samples is low. Most of the sample meets the standards of the different specifications.

In reference to the rockmass condition and the performance of samples in different test, it can be concluded that most of the rocks of the Lesser Himalaya of Malekhu area are durable enough to recommend for wide range of end uses adopting the standards of different specifications. Quartzites, siliceous dolomites and psammatic schists are found to be more suitable for construction aggregates compared to slate, phyllite, metasandstone, and gneiss.

\section{ACKNOWLEDGEMENTS}

Authors are thankful to J.L. Singh and P. Maharjan for their assistance during sampling. Authors also thank Central Department of Geology for providing necessary facility.

\section{REFERENCES}

Amah, E. A. Esu, E. O., Oden, M. I., Anam, G. 2012. Evaluation of Old Netim Basement Rocks (South-Eastern Nigeria) for Construction Aggregates. Journal of Geography and Geology. Vol 4, No 3, pp. 90-198. https://doi.org/10.5539/jgg.v4n3p90

Akesson, U., Lindqvist, J.E. \& Goransson, M. 2001.Relationship between texture and mechanical properties of granite, Central Sweden, by use of ImageAnalysing Techniques. Bulletin of Engineering Geology and The Environment, v. 60, pp. 277-1284. https://doi.org/10.1007/s100640100105

Al-Harthi, A.A. 2001. A field index to determine the strength 
characteristic of crushed aggregate. Bulletin of Engineering Geology and the Environment 60, pp. 1-114. https://doi.org/10.1007/s100640100107

ASTM, 1981. Test for resistance to degradation of large sized coarse aggregates by abrasion and impacts in the Los Angeles Machine.

ASTM, 1989. Test for resistance to abrasion of coarse aggregate particle by use of the Los Angeles machine, specification C131, American Standard of Testing Materials Standards.

ASTM, 1994, Standard Specification for Transportation Materials and Methods for sampling, Washington.

ASTM International, 2005.Standard test method for Soundness of Aggregates by use of sodium sulphate or magnesium sulphate.C88-05.

Azimah, H. and Colin, P., 2010. Intergranular texture of aggregates and its correlation to the physical properties. Sains Malaysiana. v. 39, no. 1, pp. 39-43.

Bieniawski, Z.T., 1975. The point load test in Geotechnical Practice: Eng. Geol., Vol. 9, pp. 1-11.

https://doi.org/10.1016/0013-7952(75)90024-1

Bieniawski, Z.T., 1989. Engineering rock mass classifications. John Wiley and Sons, pp-251

Christensen, B.J., Mason, T.O. and Jennings, H.M.: 1996, Comparison of measured and calculated permeabilities for hardened cement pastes. Cement and Concrete Research, Vol. 26, No. 9, pp. 1325-1334. https://doi.org/10.1016/0008-8846(96)00130-5

Dhakal, G.P., Kodma J. and Goto J., 2006. Freezing-Thawing effect and slake durability of some rocks from cold regions of Nepal and Japan, Nepal Geological Society, v.33, pp. 45-54.

DOR, 2001. Standard Specification for Road and Bridge Works, Report of Ministry of Physical Planning and Works, pp. 600-1200.

Harrison, D. J., 1992. Industrial minerals laboratory, manual: limestone, British Geological Survey Technical Report WG/92/29.

Haskins, D.R. and Bell, F.G., 1995. Drakensberg basalts: their alteration, breakdown and durability.

ISRM, 1979, Suggested methods for determining water content, porosity, density, water absorption and related properties and swelling and slake-durability index properties. Intl. soc. Rock, mech. min. sci. and Geotech.Abstr., v.16, pp. 141-156.

Khanal, S. and Tamrakar, N.K., 2009. Evaluation and quality of crushed- limestone and siltsone for road aggregates, Bulletin of Department of Geology, T.U., Kathmandu, Nepal. Vol. 12, pp. 29-42. DOI: http://dx.doi.org/10.3126/bdg.v12i0.2248

Maharjan, D.K. and Tamrakar, N.K., 2003. Quality of Siltstones for Concrete Aggregates from Nallu Khola Area, Kathmandu, Nepal Geological Society, vol. 30, pp. 167-176.

Maharjan, S. and Tamrakar, N.K., 2007. Evaluation of gravel for concrete and road aggregates, Rapti River, Central Nepal Sub-Himalaya. Bulletin of Department of Geology, Tribhuvan University, Kathmandu, Nepal, Vol. 10, pp. 99-106. DOI: http://dx.doi.org/10.3126/bdg.v10i0.1425

Mehta and Monterio, 1993, Concrete structure, properties, and materials, prentice- hall, Inc., Englewood cliffs, NJ.

NS, 1994. Nepal Standards. NS-297.

Paige-green, P., 2004. Durability testing of basic crystalline rocks and specification for use as road base aggregate. CSIR Built Environment. South Africa, 31p.

Prrikryl, R. 2001. Some microstructure aspects of strength variation in rocks. Int. Jour. of Rock Mechanics and Mining Sciences v. 38, no.1, pp. 671-682. https://doi.org/10.1016/S1365-1609(01)00031-4

Raghubansi, U. and Tamrakar, N.K., 2011. Construction material assessment from quarry sites at Chaktan-GhasaKaligandaki Area, Western Nepal, Bulletin of Department of Geology, Tribhuvan University, Kathmandu, Nepal. V o 1. $14, \quad$ p p $77-82$. http://dx.doi.org/10.3126/bdg.v14i0.5442

Roberts, M.J., Marsh R. New, A.L., and Wood, R.A., 1996, An intercomparison of a Bryan-Cox-type ocean model and on isopycnic ocean model, Part I: The superior gyre and high latitude processes.

Scholtz, T.V., and Brown. S.F., 1996. Factors affecting the durability of bituminous paving mixtures, pp. 173-190. In Cabrera, J.G., and J. R. Dixon (Eds.). Performance and Durability of Bituminous Materials. E \& FN Spon, London, UK.

Smith, M.R. and Collis, L., 1993. Sand, Gravel and Crushed Rock Aggregates for Construction Purpose, Geo. Soc. London, Specia; Publication, Vol. 9, pp. 5-263.

Sprunt, E. S., \& Brace, W. F. (1974).Direct observation of microcarvities in crystalline rocks. J. Rocks Min. Sci., v. 11, no. 4, 139-150. https://doi.org/10.1016/01489062(74)92874-5

Stocklin J., Bhattarai K.D. (1977). Geology of the Kathmandu area and Central Mahabharat Range, Nepal Himalaya. Report of Dept. Mines and Geology/ UNDP unpublished. $86 \mathrm{p}$.

Stocklin, T. (1980). Geology of Nepal and its regional frame. Journal of the Geological society London, v. 137, 1-34. https://doi.org/10.1144/gsjgs.137.1.0001 
Suparma, L.B., 2001, The Use of Recycled Waste Plastics in Bituminous Composite, Dissertation, Unpublished, The University of Leeds, Leeds.

Tamrakar, N. K., Yokota, S. and Shrestha S. D., 2002. Physical and geomechanical properties of the Siwalik Sandstones, Amlekhgunj-Suparitar Area, Cenetral Nepal Himalaya, Journal of Nepal Geological Society, v. 26, pp. 59-71.

Tamrakar, N. K., Yokota, S. and Shrestha S. D., 2007. Relationship among Mechanical, Physical and Petrographic Properties of Siwalik Sandstones, Central Nepal Sub-Himalayas, Engineering Geology, v. 90, pp. 105-123. https://doi.org/10.1016/j.enggeo.2006.10.005

Wang, H. F., \& Simmons, G. (1978). Microcracks in crystalline rock from $5.3 \mathrm{~km}$ depth in the Michigan Basin. J. Geophys. Res., 83(B12), pp. 849-856. https://doi.org/10.1029/JB083iB12p05849 